\title{
Receptor and Transmitter Release Properties Set the Time Course of Retinal Inhibition
}

\author{
Erika D. Eggers and Peter D. Lukasiewicz \\ Department of Ophthalmology and Visual Sciences, Washington University, St. Louis, Missouri 63110
}

\begin{abstract}
Synaptic inhibition is determined by the properties of postsynaptic receptors, neurotransmitter release, and clearance, but little is known about how these factors shape sensation-evoked inhibition. The retina is an ideal system to investigate inhibition because it can be activated physiologically with light, and separate inhibitory pathways can be assayed by recording from rod bipolar cells that possess distinct glycine, $\mathrm{GABA}_{\mathrm{A}}$, and $\mathrm{GABA}_{\mathrm{C}}$ receptors $(\mathrm{R})$. We show that receptor properties differentially shape spontaneous IPSCs, whereas both transmitter release and receptor properties shape light-evoked (L) IPSCs. GABA ${ }_{C} R$-mediated IPSCs decayed the slowest, whereas glycineR- and $\mathrm{GABA}_{\mathrm{A}} \mathrm{R}$-mediated IPSCs decayed more rapidly. Slow $\mathrm{GABA}_{\mathrm{C}} \mathrm{Rs}$ determined the L-IPSC decay, whereas GABA ${ }_{A} \mathrm{Rs}$ and glycineRs, which mediated rapid onset responses, determined the start of the L-IPSC. Both fast and slow inhibitory inputs distinctly shaped the output of rod bipolar cells. The slow $\mathrm{GABA}_{\mathrm{C}} \mathrm{Rs}$ truncated glutamate release, making the A17 amacrine cell L-EPSCs more transient, whereas the fast $\mathrm{GABA}_{\mathrm{A}} \mathrm{R}$ and glycineRs reduced the initial phase of glutamate release, limiting the peak amplitude of the L-EPSC. Estimates of transmitter release time courses suggested that glycine release was more prolonged than GABA release. The time course of $\mathrm{GABA}$ release activating $\mathrm{GABA}_{\mathrm{C}} \mathrm{Rs}$ was slower than that activating $\mathrm{GABA}_{\mathrm{A}} \mathrm{Rs}$, consistent with spillover activation of $\mathrm{GABA}_{\mathrm{C}} \mathrm{Rs}$. Thus, both postsynaptic receptor and transmitter release properties shape light-evoked inhibition in retina.
\end{abstract}

Key words: inhibition; light; retina; $\mathrm{GABA}_{\mathrm{A}}$ receptor; $\mathrm{GABA}_{\mathrm{C}}$ receptor; glycine receptor; spillover; IPSC; glycine; $\mathrm{GABA}$; patch-clamp

\section{Introduction}

Inhibitory signals are determined by the properties of neurotransmitter receptors, release, and clearance. Changes in $\mathrm{GABA}_{\mathrm{A}}$ and glycine receptor $(\mathrm{R})$ subunit expression during development contribute to the speeding of inhibition (Takahashi et al., 1992; Dunning et al., 1999; Okada et al., 2000). In the cerebellum, $\alpha 1$ containing $\mathrm{GABA}_{\mathrm{A}}$ receptors mediate fast, synaptic inhibition, whereas $\alpha 6$-containing $\mathrm{GABA}_{\mathrm{A}}$ receptors mediate slow, tonic inhibition (Brickley et al., 1996; Hamann et al., 2002). Differences in GABA release contribute to hippocampal signaling, because either synchronous or asynchronous release from distinct interneurons produces either brief or prolonged inhibition (Hefft and Jonas, 2005). Additionally, at some synapses neurotransmitter diffuses or spills over from release sites and activates receptors at neighboring synapses. When spillover transmission is enhanced by decreasing transmitter clearance, the decay time of inhibitory synaptic currents are prolonged, suggesting that spillover between synapses shapes inhibition (Chiu et al., 2005; Keros and Hablitz, 2005). However, little is known about how these prop-

Received March 16, 2006; revised Aug. 2, 2006; accepted Aug. 6, 2006.

This work was supported by National Institutes of Health Grants T32 EY13360 and F32 EY15629 (E.D.E.), EY08922 (P.D.L.), and EY02687 (Washington University Department of Ophthalmology), Research to Prevent Blindness, and The M. Bauer Foundation. We thank Drs. Tomomi Ichinose, Botir T. Sagdullaev, and Steve Mennerick for helpful discussion and comments on this manuscript and James Debrecht for technical assistance.

Correspondence should be addressed to Peter D. Lukasiewicz, Department of Ophthalmology, Campus Box 8096 Washington University School of Medicine, 660 South Euclid Avenue, St. Louis, M0 63110. E-mail: lukasiewicz@ vision.wustl.edu.

DOI:10.1523/JNEUROSCI.2591-06.2006

Copyright $\odot 2006$ Society for Neuroscience $\quad$ 0270-6474/06/269413-13\$15.00/0 erties determine the time course of inhibition evoked by sensory stimuli.

To investigate the roles of receptor properties, neurotransmitter release, and clearance on sensory processing, we studied visually evoked inhibition in the retina, which can be activated physiologically with light. Furthermore, the circuitry and receptor expression patterns of the retina are well defined. Rod bipolar cells, which receive inhibition that is mediated by glycine, $\mathrm{GABA}_{\mathrm{A}}$, and $\mathrm{GABA}_{\mathrm{C}}$ receptors (Eggers and Lukasiewicz, 2006), are ideal for studying distinct inhibitory inputs. We do not know whether the different temporal properties of these receptors (Amin and Weiss, 1994; Feigenspan and Bormann, 1994; Lukasiewicz and Shields, 1998; McCall et al., 2002; Frech and Backus, 2004) shape light-evoked (L) inhibition or whether the receptors are activated by distinct neurotransmitter release time courses. Using receptor-specific blockers and mice that lack $\mathrm{GABA}_{\mathrm{C}}$ receptors (McCall et al., 2002), we determined that GABA and glycine receptor properties, transmitter release, and spillover shaped L-IPSCs. These diverse presynaptic inhibitory signals differentially shaped the output of rod bipolar cells: prolonged, $\mathrm{GABA}_{\mathrm{C}}$ receptor-mediated inhibition limited the dura-

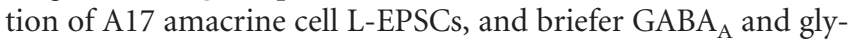
cine receptor-mediated inhibition affected the initial peak of the L-EPSCs.

\section{Materials and Methods}

Preparation of mouse retinal slices. Animal protocols were approved by the Washington University School of Medicine Animal Studies Committee. In this study, we use wild-type (WT) mice (C57BL/6J strain; The Jackson Laboratory, Bar Harbor, ME) and $\mathrm{GABA}_{\mathrm{C}} \rho 1$ null mice that 
lacked functional $\mathrm{GABA}_{\mathrm{C}}$ receptors (crossed onto the $\mathrm{C} 57 \mathrm{BL} / 6 \mathrm{~J}$ background) (McCall et al., 2002). The experimental techniques were similar to those described in our previous studies (Shields et al., 2000; McCall et al., 2002; Eggers and Lukasiewicz, 2006). Briefly, mice were dark-adapted overnight, and all dissection and recording procedures were performed under infrared illumination to preserve the light sensitivity of the preparations. Mice 28-90 d of age were killed using carbon dioxide, their eyes were enucleated, and the cornea, lens, and vitreous were removed. The eyecup was incubated for $20 \mathrm{~min}$ in dissection and storage solution (see electrode and bath solutions) with hyaluronidase $(0.5 \mathrm{mg} / \mathrm{ml}$; Sigma, St. Louis, MO) to facilitate vitreous removal. The hyaluronidase solution was replaced with cold, oxygenated storage solution, the retina was dissected out of the eyecup, and $250 \mu \mathrm{m}$ slices were prepared from the isolated retina and maintained in oxygenated storage solution at room temperature (Werblin, 1978; McCall et al., 2002).

Whole-cell recordings. Whole-cell patch recordings were made from bipolar cells and amacrine cells from retinal slices as described previously (McCall et al., 2002; Eggers and Lukasiewicz, 2006). IPSCs were recorded from retinal bipolar cells voltage clamped to $0 \mathrm{mV}$, the reversal potential for currents mediated by nonselective cation channels. EPSCs were recorded from amacrine cells voltage clamped to $-60 \mathrm{mV}$, the reversal potential for IPSCs. All recordings were made at $32^{\circ} \mathrm{C}$. Liquid junction potentials of $15 \mathrm{mV}$ were corrected for at the beginning of each recording.

The recording procedures and microscope system have been described previously (Lukasiewicz and Roeder, 1995). Electrodes were pulled from borosilicate glass (1B150F-4; World Precision Instruments, Sarasota, FL) on a P97 Flaming/Brown puller (Sutter Instruments, Novato, CA) and had resistances of $<5 \mathrm{M} \Omega$. Patchit software (White Perch Software, Somerville, MA) was used to generate voltage command outputs, acquire data, and gate the drug perfusion valves. The data were digitized and stored with a personal computer using a Labmaster DMA data acquisition board (Scientific Solutions, Solon, OH). Responses were filtered at 1 $\mathrm{kHz}$ with the four-pole Bessel filter on the Axopatch 200B (Molecular Devices, Palo Alto, CA) and sampled at $2-5 \mathrm{kHz}$. The preparation was heated by temperature-controlled thin-stage and in-line heaters (Cell Microcontrols, Norfolk, VA).

Morphological identification of retinal cell types. Bipolar cells and amacrine cells were identified by their characteristic morphology and cell stratification within the ON and OFF sublaminas of the retinal inner plexiform layer after labeling with either Lucifer yellow $(0.05 \%)$ or Sulforhodamine B $(0.005 \%)$, included in the recording electrode (Euler and Wässle, 1998; Shields et al., 2000; Eggers and Lukasiewicz, 2006).

Solutions and drugs. The dissection and storage solution contained the following (in mM): $137 \mathrm{NaCl}, 2.5 \mathrm{KCl}, 1 \mathrm{MgCl}_{2}, 2.5 \mathrm{CaCl}_{2}, 28$ glucose, and 10 HEPES, adjusted to $\mathrm{pH} 7.4$ with $\mathrm{NaOH}$ and bubbled with oxygen. The extracellular recording solution contained the following (in $\mathrm{mM}$ ): $125 \mathrm{NaCl}, 2.5 \mathrm{KCl}, 1 \mathrm{MgCl}_{2}, 1.25 \mathrm{NaH}_{2} \mathrm{PO}_{4}, 2 \mathrm{CaCl}_{2}, 20$ glucose, and 26 $\mathrm{NaHCO}_{3}$, bubbled with carbogen $\left(95 \% \mathrm{O}_{2}-5 \% \mathrm{CO}_{2}\right)$. The intracellular solution contained the following (in $\mathrm{mM}$ ): $120 \mathrm{Cs}$ gluconate, $1 \mathrm{CaCl}_{2}, 1$ $\mathrm{MgCl}_{2}, 10 \mathrm{Na}$-HEPES, 11 EGTA, 10 tetraethylammonium-Cl, adjusted to $\mathrm{pH} 7.2$ with $\mathrm{CsOH}$. To isolate receptor types, strychnine ( $500 \mathrm{nM}$ ) was used to block glycine receptors, bicuculline methobromide (50 $\mu \mathrm{M}$; Research Biomedicals, Natick, MA) to block GABA $_{\mathrm{A}}$ receptors and $(1,2,5,6$ tetrahydropyridine-4yl) methylphosphinic acid (TPMPA) (50 $\mu \mathrm{M}$; Research Biomedicals) to block $\mathrm{GABA}_{\mathrm{C}}$ receptors. Kainate $(10 \mu \mathrm{M})$ was used to elicit spontaneous $\mathrm{GABA}_{\mathrm{C}}$ receptor-mediated IPSCs. NO-711 (1-[2([(diphenylmethylene)imino] oxy)ethyl]-1,2,5,6-tetrahydro-3pyridinecarboxylic acid hydrochloride) was used ( $5 \mu \mathrm{M})$ to block GAT-1 GABA transporters. Antagonists were applied to the slice by a gravitydriven superfusion system, as described previously (Lukasiewicz and Roeder, 1995). Unless otherwise indicated, all chemicals were obtained from Sigma.

Light stimulation. To evoke L-IPSCs and L-EPSCs, full-field light stimuli were generated using a light-emitting diode (LED) (HLMP-3950, $\lambda_{\text {peak }}=565 \mathrm{~nm}$; Agilent, Palo Alto, CA) that was positioned near the microscope stage. The intensity of the unattenuated light was $1.85 \times 10^{5}$ photons $/ \mu \mathrm{m}^{2} / \mathrm{s}$. Light intensity was controlled by varying the current through the LED. Light stimuli were attenuated $-2 \log$ units, unless otherwise stated.

Data analysis. Tack (White Perch Software) and Clampfit (Molecular Devices) software were used to average records and to measure the peak, time-to-peak, rise time, charge transfer $(Q)$, decay time, and half-width of the light-evoked current responses for each cell or the simulated current responses. Unless otherwise stated, all analysis and traces displayed of light-evoked currents were from the average of two responses from the same cell. The decay time was measured by computing the $D_{37}$, the time at which the current had declined to $37 \%$ of its peak amplitude. Student's $t$ tests (two-tailed, unequal variance) were used to compare these response parameters from wild-type and $\mathrm{GABA}_{\mathrm{C}} \mathrm{R}$ null neurons. Paired Student's $t$ tests were used to compare values between conditions for the same cell. Differences were considered significant when $p \leq 0.05$. All data are reported as mean \pm SEM.

Spontaneous IPSCs (sIPSCs) were analyzed using Mini Analysis (Synaptosoft, Decatur, GA). sIPSCs were selected so that the rise and decay phases did not contain any overlapping events. For each individual sIPSC, the amplitude was measured, and the $\tau_{\text {decay }}$ was calculated by fitting an exponential function to the decay from the peak to baseline. The distributions of sIPSC amplitude and $\tau_{\text {decay }}$ values were compared using the Kolmogorov-Smirnov test $(\mathrm{K}-\mathrm{S})$. To compute the average sIPSC, the events were aligned by the $50 \%$ rise time. $\mathrm{GABA}_{\mathrm{C}}$ receptormediated sIPSCs were aligned by hand, using the Clampfit program, because the events had too slow a rise time to be effectively aligned using the Mini Analysis program.

For intensity-response curves, L-IPSCs were normalized to the maximal response in control solution in WT mice, which was the maximum $Q$ of the L-IPSCs. The normalized data were plotted versus the $\log _{10}$ of the stimulus luminance $(L)$. The values were fitted using the sigmoid function: $Y=a /\left(1+e^{-(X-L 50) / b}\right)$, where $a$ is the maximum response, $b$ the Hill slope of the response, and $L_{50}$ is the $\log _{10}$ of the light intensity at the half-maximum response. The luminance evoking a half-maximal response $\left(L_{50}\right)$ and the dynamic range for the curves, which is the difference in light intensity between 20 and $80 \%$ of the maximal response $\left(L_{20-80}\right)$, were calculated using the fitted curve.

For the transmitter release time course estimates, idealized L-IPSC and sIPSC curves were computed using the average rise time, peak, and $D_{37}$ or $\tau_{\text {decay }}$ of the L-IPSCs and sIPSCs mediated by isolated $\mathrm{GABA}_{\mathrm{C}}, \mathrm{GABA}_{\mathrm{A}}$, and glycine receptors. The rising phase was described by a line, using the peak/rise time as the slope. The decay phase was calculated as an exponential decay function from the peak, using either the $D_{37}$ or $\tau_{\text {decay }}$ value as the exponential $\tau$. Release functions were calculated by convolution analysis (Diamond and Jahr, 1995) using the following relationship:

$$
\operatorname{L-IPSC}(t)=\operatorname{release}(t) \times \operatorname{sIPSC}(t),
$$

such that

$$
\text { release }(t)=F^{-1} \frac{F[\operatorname{L}-\operatorname{IPSC}(t)]}{F[\operatorname{siPSC}(t)]},
$$

where $F$ and $F^{-1}$ represent the Fourier transform and inverse Fourier transform of the function, respectively. The release estimates and simulation were calculated using Igor Pro (WaveMetrics, Oswego, OR).

\section{Results \\ Eliminating $\mathrm{GABA}_{\mathrm{C}}$ receptors shortened rod bipolar cell L-IPSC duration}

Rod bipolar cell terminals receive light-evoked presynaptic inhibition mediated by distinct glycine, $\mathrm{GABA}_{\mathrm{A}}$, and $\mathrm{GABA}_{\mathrm{C}}$ receptors (Eggers and Lukasiewicz, 2006). Although these receptors have distinct kinetic properties (Amin and Weiss, 1994; Shields et al., 2000; Frech and Backus, 2004), it is not known whether these different receptors shape light-evoked inhibition. If receptor properties are a major determinant of the light response time course, then eliminating slow $\mathrm{GABA}_{\mathrm{C}}$ receptors, either genetically or pharmacologically, should make L-IPSCs briefer. To determine whether the distinct inhibitory inputs have distinct tem- 
A.

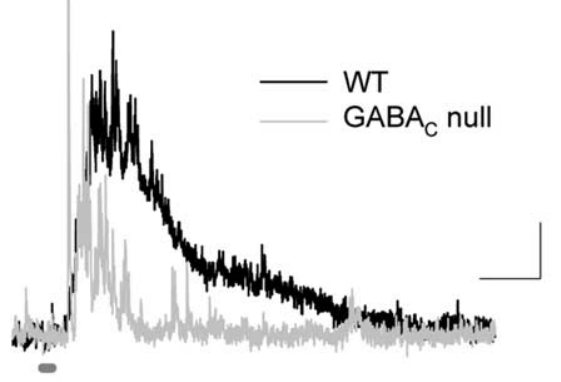

B.

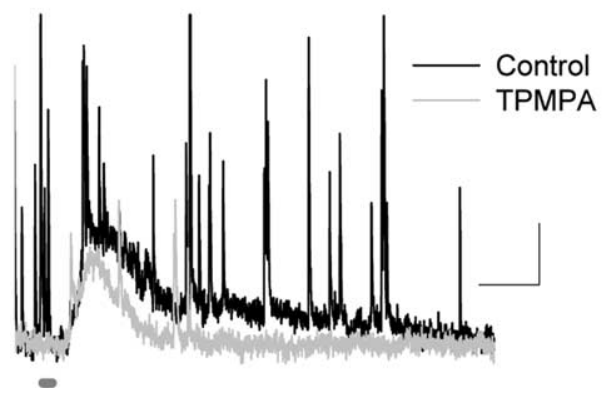

C.

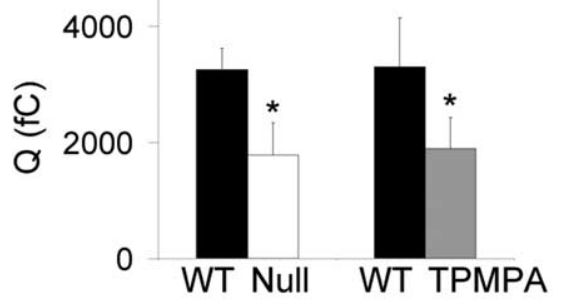

D.

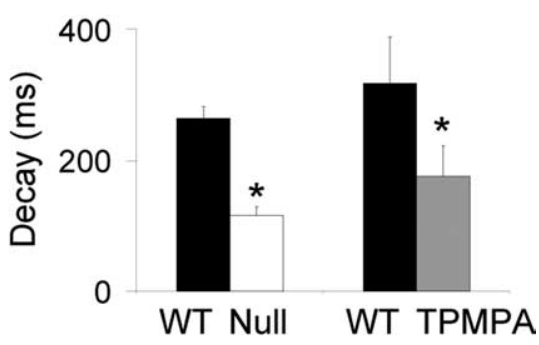

Figure 1. $\quad G_{A B A}$ receptors prolong rod bipolar cell L-IPSCS. A, L-IPSCS evoked by brief light stimuli ( $30 \mathrm{~ms}$; thick dark gray bar) were smaller and decayed faster in $\mathrm{GABA}_{C}$ R null mice (gray trace) than in WT mice (black trace). Calibration: 5 pA, 200 ms. $\boldsymbol{B}$, Blocking $G_{A B A}$ receptors with TPMPA decreased and shortened L-IPSCS (gray trace) compared with control conditions (black trace). $C$, The $Q$ in $G_{B B A} R$ null mice was significantly smaller than in WT mice ( ${ }^{*} p<0.05$ ). The $Q$ in rod bipolar cells after TPMPA application was significantly smaller than in control retinas $\left({ }^{*} p<0.05\right)$. $\boldsymbol{D}$, The L-IPSC decay $\left(D_{37}\right)$ in GABA $R$ mice was significantly briefer than for WT mice $\left({ }^{*} p<0.001\right)$. Similarly, the L-IPSC decay measured in the presence of TPMPA also was briefer than that measured in control conditions $\left({ }^{*} p<0.05\right)$.

Table 1. Parameters for L-IPSCs (30 ms light stimulus) from rod bipolar cells

\begin{tabular}{|c|c|c|c|c|c|}
\hline L-IPSC type & $D_{37}(\mathrm{~ms})$ & $Q(\mathrm{fC})$ & Peak (pA) & Time-to-peak (ms) & $n$ \\
\hline $\mathrm{GABA}_{\mathrm{A}}$ & $134.1 \pm 35.5$ & $954 \pm 371$ & $7.1 \pm 1.2$ & $158.9 \pm 12.5$ & 12 \\
\hline $\mathrm{GABA}_{\mathrm{C}}$ & $472.4 \pm 82.7$ & $3667 \pm 522$ & $10.4 \pm 1.4$ & $225.7 \pm 17.9$ & 14 \\
\hline Glycine & $279.1 \pm 28.9$ & $1635 \pm 421$ & $10.6 \pm 1.6$ & $154.0 \pm 17.5$ & 13 \\
\hline WT control & $275.3 \pm 19.8$ & $3215 \pm 368$ & $13.5 \pm 1.3$ & $168.2 \pm 9.2$ & 43 \\
\hline $\mathrm{GABA}_{C} \mathrm{R}$ null control & $119.6 \pm 14.3$ & $1775 \pm 559$ & $13.1 \pm 2.2$ & $156.7 \pm 8.9$ & 15 \\
\hline
\end{tabular}

poral properties, we recorded L-IPSCs elicited by brief $(30 \mathrm{~ms})$ light stimuli.

Figure $1 A$ shows that the L-IPSCs recorded in mice that lacked $\mathrm{GABA}_{\mathrm{C}}$ receptors $\left(\mathrm{GABA}_{C} \mathrm{R}\right.$ null) had smaller charge transfers $(p<0.05)$ (Fig. $1 C$, Table 1$)$ and briefer decay times $(p<0.001)$ (Fig. $1 D$, Table 1) compared with those recorded in WT mice. Similarly, when $\mathrm{GABA}_{\mathrm{C}}$ receptors in WT mice were blocked with TPMPA, the charge transfer $(Q$ of $3290 \pm 846 \mathrm{fC}$ reduced to $1886 \pm 538 \mathrm{fC} ; n=5 ; p<0.05$ ) (Fig. $1 B-D$ ) and decay time were decreased (control $D_{37}, 318 \pm 31 \mathrm{~ms}$ to TPMPA, $176 \pm 46 \mathrm{~ms}$; $p<0.05$ ), demonstrating that the responses from $\mathrm{GABA}_{\mathrm{C}} \mathrm{R}$ null mice were not attributable to circuitry alterations caused by the elimination of $\mathrm{GABA}_{\mathrm{C}}$ receptors, in agreement with previous reports (McCall et al., 2002; Eggers and Lukasiewicz, 2006). In $\mathrm{GABA}_{\mathrm{C}}$ null mice, the briefer L-IPSCs presumably reflect the contributions of the more rapidly decaying responses of glycine and $\mathrm{GABA}_{\mathrm{A}}$ receptors.

\section{Glycine, $\mathrm{GABA}_{\mathrm{A}}$, and $\mathrm{GABA}_{\mathrm{C}}$ receptor-mediated L-IPSCs have distinct kinetics}

Our results suggest that $\mathrm{GABA}_{\mathrm{C}}$ receptors determine the duration of L-IPSCs, but it is not known how $\mathrm{GABA}_{\mathrm{A}}$ and glycine receptors shape L-IPSCs. To determine the contributions of individual receptor types to rod bipolar cell L-IPSCs, we recorded L-IPSCs mediated by pharmacologically isolated $\mathrm{GABA}_{\mathrm{C}}, \mathrm{GABA}_{\mathrm{A}}$, and glycine receptors, from WT mice and $\mathrm{GABA}_{\mathrm{C}} \mathrm{R}$ null mice, which lack $\mathrm{GABA}_{\mathrm{C}}$ receptors (see Materials and Methods), because no significant differences were observed between $\mathrm{WT}$ and $\mathrm{GABA}_{C} \mathrm{R}$ null $\mathrm{GABA}_{\mathrm{A}}$ and glycine receptor-mediated L-IPSCs as described previously (Eggers and Lukasiewicz, 2006) or in this study $(p>0.4)$. Examples of normalized, pharmacologically isolated, glycine, $\mathrm{GABA}_{\mathrm{C}}$, and $\mathrm{GABA}_{\mathrm{A}}$ receptormediated currents, in response to a brief light stimulus $(30 \mathrm{~ms})$, are shown in Figure 2. The $\mathrm{GABA}_{\mathrm{A}}$ (Fig. $2 A 1, B 1$, Table 1) and the glycine (Fig. 2A2,B1) receptormediated L-IPSCs decayed more rapidly than the $\mathrm{GABA}_{\mathrm{C}}$ receptor-mediated L-IPSCs. The decay of the $\mathrm{GABA}_{\mathrm{C}}$ receptor-mediated L-IPSCs was significantly longer than the decay of the $\mathrm{GABA}_{\mathrm{A}}$ receptor-mediated L-IPSCs $(p<0.01)$ (Fig. 2 B1, Table 1) and, on average, longer than glycine receptor-mediated L-IPSCs $(p<0.08)$. Additionally, the glycine receptor-mediated L-IPSCs were significantly longer than the $\mathrm{GABA}_{\mathrm{A}}$ receptormediated L-IPSCs $(p<0.01)$.

The times to the peak of the pharmacologically isolated L-IPSCs (measured from stimulus onset) differed; $\mathrm{GABA}_{\mathrm{A}}$ and glycine receptor-mediated responses increased faster than $\mathrm{GABA}_{\mathrm{C}}$ receptormediated responses (Fig. 2B2). The time-to-peak of $\mathrm{GABA}_{\mathrm{A}}$ and glycine receptor-mediated L-IPSCs were similar to each other $(p=0.8)$ (Table 1) but significantly faster than the time-to-peak for the $\mathrm{GABA}_{\mathrm{C}}$ receptor-mediated L-IPSCs $(p<0.01)$ (Table 1$)$. These findings suggest that the initial peak value of WT bipolar cell L-IPSCs was determined by $\mathrm{GABA}_{\mathrm{A}}$ and glycine receptormediated inputs because the $\mathrm{GABA}_{\mathrm{C}}$ receptor-mediated current increased too slowly to affect the initial part of the response. This idea was confirmed by comparing the L-IPSCs from rod bipolar cells in WT and $\mathrm{GABA}_{\mathrm{C}} \mathrm{R}$ null mice. There were no significant differences between their time-to-peak $(p=0.4)$ (Table 1) or peak amplitudes $(p=0.9)$ (Table 1$)$, although, as expected, their decay times differed (Fig. 1, Table 1). There was also no significant difference between the timeto-peak values for WT L-IPSCs and the isolated glycine and $\mathrm{GABA}_{\mathrm{A}}$ receptor-mediated L-IPSCs $(p=0.5)$, whereas the isolated $\mathrm{GABA}_{C}$ receptor-mediated L-IPSCs had a significantly slower time-to-peak than WT L-IPSCs $(p<0.05)$.

The time course of L-IPSCs is determined not only by the kinetic properties of individual receptor-mediated components but also by the magnitude of the current mediated by each receptor type. We therefore determined the charge transfer $(Q)$ (Fig. $2 \mathrm{C} 1$, Table 1) and peak current amplitude (Fig. 2C2) of each receptor-mediated component, in response to brief light stimuli. $\mathrm{GABA}_{\mathrm{C}}$ receptors mediated the largest charge transfer, whereas 

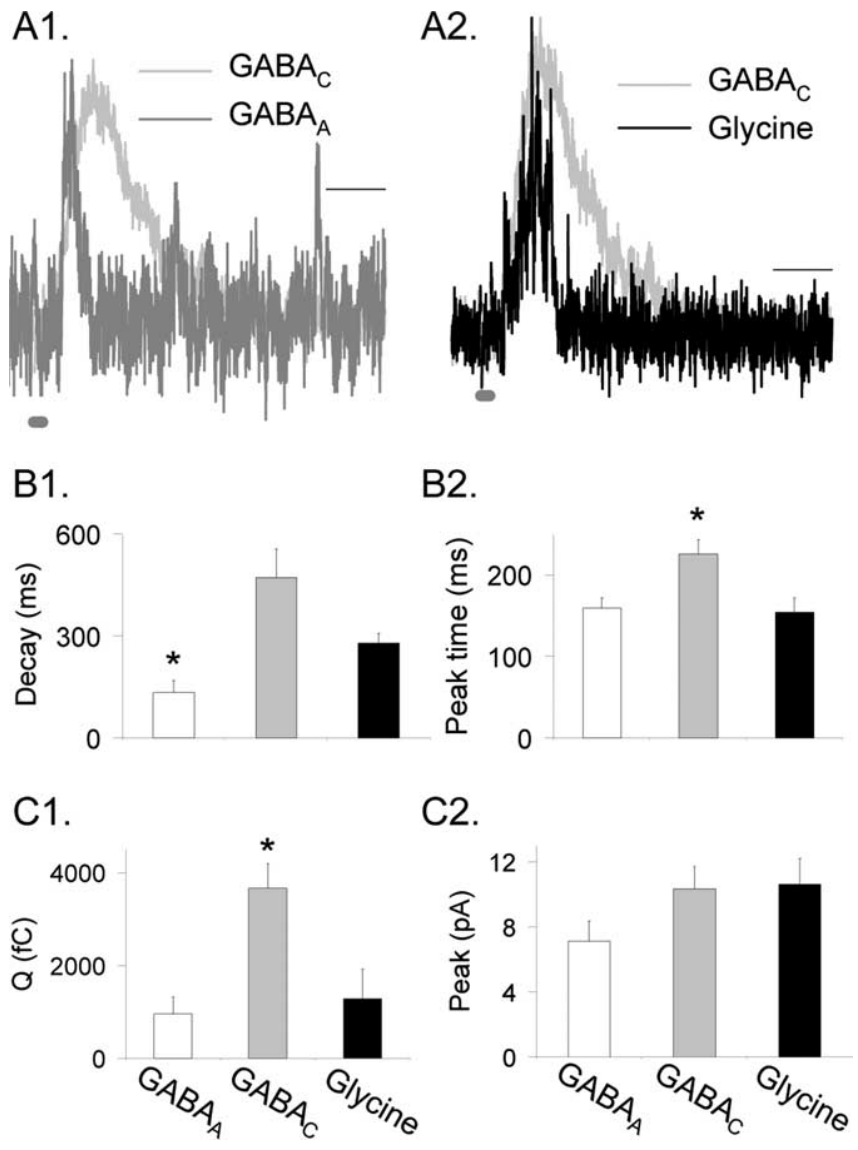

Figure 2. Glycine, $G_{A B A}$, and $G A B A_{C}$ receptors mediated L-IPSCs, with different properties. $\boldsymbol{A} \mathbf{1}$ and $\boldsymbol{A} 2$ show pharmacologically isolated and peak-scaled L-IPSCs evoked by a $30 \mathrm{~ms}$ light stimulus (dark gray bar at bottom of trace) mediated by $G_{A B A_{A},} G_{B B A}$, and glycine receptors. $G_{C A B}$ receptors mediated L-IPSC $s$ with a slower decay time than those mediated by $G_{A B A}$ or glycine receptors. Calibration, $200 \mathrm{~ms}$. B1, The $D_{37}$ was measured from L-IPSCs mediated by isolated glycine (black), GABA (white), and $\mathrm{GABA}_{C}$ (gray) receptors. GABA $\mathrm{A}_{\mathrm{A}}$ L-IPSCs had a significantly briefer $D_{37}$ than either glycine receptors or $\mathrm{GABA}_{C}$ receptors; ${ }^{*} p<0.01$. Glycine receptor-mediated L-IPSCS were on average briefer than $\mathrm{GABA}_{C}$ receptor-mediated L-IPSCS $(p<0.08)$. B2, GABA receptor-mediated L-IPSCS had a longer time-to-peak than either glycine or $\mathrm{GABA}_{A}$ receptor-mediated L-IPSCs; ${ }^{*} p<0.01$. There was no significant difference in timeto-peak between $\mathrm{GABA}_{A}$ and glycine L-IPSCS $(p=0.8)$. C1, GABA ${ }_{C}$ receptor-mediated L-IPSCs had significantly larger $Q$ than either $\mathrm{GABA}_{\mathrm{A}}$ or glycine L-IPSCS $(p<0.01)$. There was no significant difference in $Q$ between $\mathrm{GABA}_{A}$ and glycine L-IPSCS $(p=0.3)$. $\mathbf{C 2}, \mathrm{GABA}_{\mathrm{A}}$ receptor-mediated L-IPSCS on average had a smaller peak value than $\mathrm{GABA}_{C}$ and glycine $\mathrm{L}-\mathrm{IPSCS}(p<0.1)$.

glycine $(p<0.01)$ (Table 1$)$ and GABA $_{\mathrm{A}}(p<0.01)$ (Table 1$)$ mediated significantly smaller charge transfers.

The peak amplitude of the rapidly responding $\mathrm{GABA}_{\mathrm{A}}$ and glycine receptors is important in determining how inhibition affects the early component of glutamate release. We compared the peak amplitudes of L-IPSCs mediated by glycine, GABA ${ }_{\mathrm{A}}$, and $\mathrm{GABA}_{\mathrm{C}}$ receptors. $\mathrm{GABA}_{\mathrm{A}}$ receptor-mediated L-IPSCs were the smallest (Table 1) and were smaller, but not significantly different, than the glycine $\left(p<0.1\right.$ vs $\left.\mathrm{GABA}_{\mathrm{A}}\right)$ and the $\mathrm{GABA}_{\mathrm{C}}(p<$ 0.1 vs $G_{A B A_{A}}$ ) receptor-mediated L-IPSCs. The peak values of glycine and $\mathrm{GABA}_{C}$ receptor-mediated L-IPSCs were similar $(p=0.9)$. Because the $\mathrm{GABA}_{\mathrm{A}}$ or glycine receptor-mediated L-IPSCs rise faster than $\mathrm{GABA}_{\mathrm{C}} \mathrm{L}$-IPSCs and are similar to the time-to-peak values of the total WT L-IPSCs, our findings suggest that glycine and $\mathrm{GABA}_{\mathrm{A}}$ receptors determine the time-topeak and $\mathrm{GABA}_{\mathrm{C}}$ receptors determine the decay time of WT L-IPSCs.
$\mathrm{GABA}_{\mathrm{C}}$ receptor-mediated inhibition limits the extent of rod bipolar cell glutamate release

If $\mathrm{GABA}_{\mathrm{C}}$ receptors prolong the duration of inhibition at rod bipolar cell terminals, then $\mathrm{GABA}_{\mathrm{C}}$ receptor-mediated inhibition should limit glutamate release from rod bipolar cells. To assess light-evoked glutamate release, we recorded L-EPSCs from morphologically identified A17 amacrine cells that receive excitatory input from rod bipolar cells. To determine whether $\mathrm{GABA}_{\mathrm{C}}$ receptor-mediated inhibition limits glutamate release from rod bipolar cells, we compared L-EPSCs recorded from $\mathrm{GABA}_{\mathrm{C}}$ null and WT mice in the absence or presence of TPMPA.

Figure $3 A$ shows that L-EPSCs recorded from A17 amacrine cells in response to a brief light stimulus $(30 \mathrm{~ms})$ had a slower decay in mice that lacked $\mathrm{GABA}_{\mathrm{C}}$ receptors compared with WT cells. Consistent with the notion that $\mathrm{GABA}_{\mathrm{C}}$ receptor-mediated inhibition limits glutamate output from rod bipolar cells, we found that $\mathrm{GABA}_{\mathrm{C}} \mathrm{R}$ null L-EPSCs decayed more slowly (WT $D_{37}$, $304.2 \pm 78.7 \mathrm{~ms}, n=9$; $\mathrm{GABA}_{\mathrm{C}} \mathrm{R}$ null $D_{37}, 506.6 \pm 48.3 \mathrm{~ms}, n=$ $7 ; p<0.05$ ) (Fig. 3C) and exhibited larger, but not significantly different, charge transfers than WT L-EPSCs (WT Q, -9960 \pm $2548 \mathrm{fC} ; \mathrm{GABA}_{\mathrm{C}} \mathrm{R}$ null $\left.\mathrm{Q},-15804 \pm 6402 \mathrm{fC}\right)$. We obtained similar results when L-EPSCs were recorded from WT A17 amacrine cells and $\mathrm{GABA}_{\mathrm{C}}$ receptors were blocked with TPMPA (Fig. $3 B, C)$; TPMPA increased the $D_{37} 32.3 \pm 6.4 \%(p<0.01 ; n=9)$ and the $Q 23 \pm 8.9 \%(p<0.05)$. These results suggest that $\mathrm{GABA}_{\mathrm{C}}$ receptors limit the extent of glutamate release from rod bipolar cells.

Glycine and $\mathrm{GABA}_{\mathrm{A}}$ receptor-mediated inhibition decreased the initial phase of glutamate release from rod bipolar cells We show above (Fig. 3 ) that the slowly responding $\mathrm{GABA}_{\mathrm{C}}$ receptors have a large influence on the time course of glutamate release from rod bipolar cells. Because $\mathrm{GABA}_{\mathrm{C}}$ receptors primarily affect the decay time and not the peak amplitude or peak time of L-IPSCs, we would expect that $\mathrm{GABA}_{\mathrm{C}}$ receptors would not have a significant effect on the initial peak of A17 amacrine cell L-EPSCs. We observed no significant change in peak (WT, $-19.1 \pm 3.1 \mathrm{pA} ; \mathrm{GABA}_{\mathrm{C}} \mathrm{R},-21.7 \pm 7.0 ; p=0.8$ ) or time-to-peak (WT, $185.0 \pm 30.6 ; \mathrm{GABA}_{\mathrm{C}} \mathrm{R}$ null, $160.2 \pm 19.4 ; p=0.5$ ) between L-EPSCs in WT and GABA $_{C}$ R null mice, suggesting that the early phase of glutamate release from rod bipolar cells was determined by the more rapidly responding $\mathrm{GABA}_{\mathrm{A}}$ and glycine receptors.

To test this, we recorded L-EPSCs from A17 amacrine cells from $\mathrm{GABA}_{\mathrm{C}} \mathrm{R}$ null mice in response to a brief $(30 \mathrm{~ms})$ light stimulus to isolate the effects of $\mathrm{GABA}_{\mathrm{A}}$ and glycine receptors. We used $\mathrm{GABA}_{\mathrm{C}} \mathrm{R}$ null mice to assess the contribution of $\mathrm{GABA}_{\mathrm{A}}$ receptors to bipolar cell inhibition because blocking $\mathrm{GABA}_{\mathrm{A}}$ receptors with bicuculline produced network effects in WT mice, resulting in increased $\mathrm{GABA}_{\mathrm{C}}$ receptor-mediated inhibition (Eggers and Lukasiewicz, 2006). The contributions of glycine and $\mathrm{GABA}_{\mathrm{A}}$ receptors were determined after the addition of strychnine or bicuculline, respectively (Fig. $4 A, B$ ). Strychnine increased the peak L-EPSC amplitude $26.8 \pm 7.7 \%(p<0.05 ; n=$ 5) (Fig. $4 C$ ) but had no significant effect on the L-EPSC decay $\left(D_{37}\right.$ reduced $\left.5.2 \pm 8.9 \% ; p=0.4\right)$. Similarly, bicuculline increased the peak L-EPSC amplitude $(14.0 \pm 2.3 \%$; $p<0.05)$ (Fig. $4 C)$ but did not alter the L-EPSC decay $\left(D_{37}\right.$ reduced $14.4 \pm$ $14.1 \% ; p=0.5 ; n=5)$. Our results demonstrate that the rapidly responding glycine and $\mathrm{GABA}_{\mathrm{A}}$ receptors limited the initial component of glutamate release, whereas the slowly responding $\mathrm{GABA}_{\mathrm{C}}$ receptors limit prolonged glutamate release and had little effect on the initial component of release. 


\section{A.}

$$
\begin{aligned}
& \text { WT } \\
& \text { GABA }{ }_{C} R \text { null }
\end{aligned}
$$

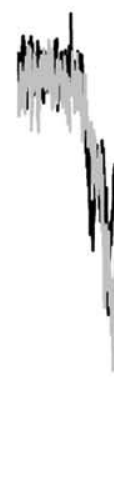

\section{B.}
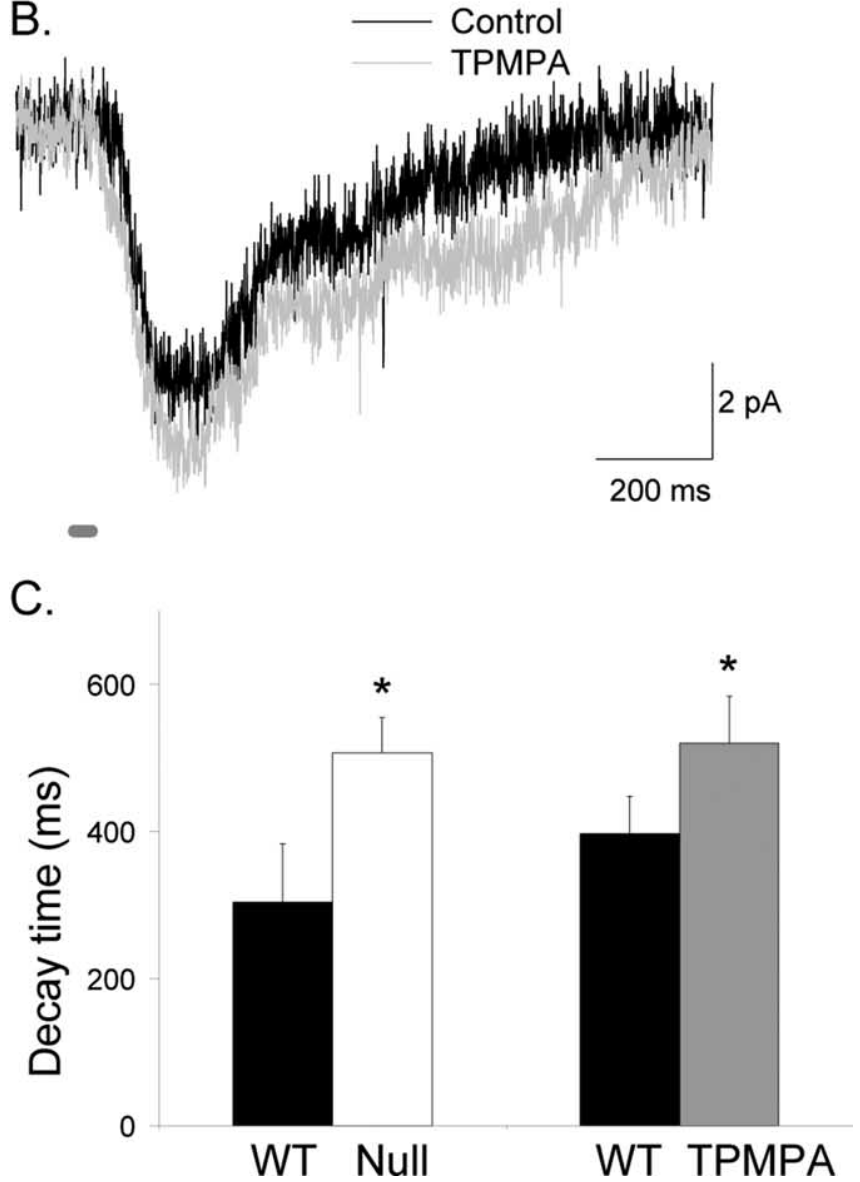

Figure 3. Presynaptic $\mathrm{GABA}_{C}$ receptors make L-EPSCs from $\mathrm{A} 17$ amacrine cells more transient. $A$, Shown are L-EPSCs ( 30 ms light stimulus; dark gray bay) from A17 amacrine cells from WT and GABA $R$ null mice. The absence of $G A B A_{C}$ receptors in $G A B A_{C} R$ null mice causes the $L$-EPSC to have a longer decay and larger charge transfer. $B$, A similar effect was observed in WT mice when TPMPA was added to block $G A B A_{C}$ receptors. $C$, The decay $\left(D_{37}\right)$ of $A 17$ amacrine cells from $\mathrm{GABA}_{C}$ R null mice $\left.{ }^{*} p<0.05\right)$ and WT mice in TPMPA $\left({ }^{*} p<0.01\right)$ was significantly longer than WT mice in control conditions.

$\mathrm{GABA}_{\mathrm{A}}$, glycine, and $\mathrm{GABA}_{\mathrm{C}}$ receptor-mediated sIPSCs have different properties

Our results suggest that the distinct inhibitory receptors mediate different temporal properties of light-evoked inhibition. However, L-IPSCs are also shaped by the time course of neurotransmitter release. Therefore, we determined the receptor properties that underlie the L-IPSCs by characterizing the temporal proper-
A.
Control Strychnine

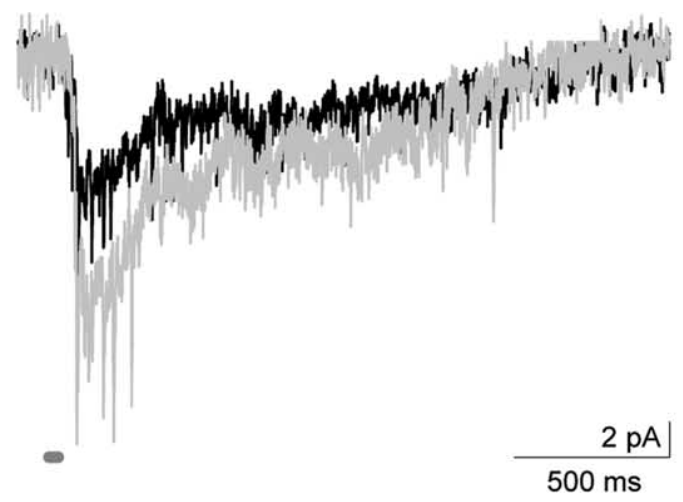

B.
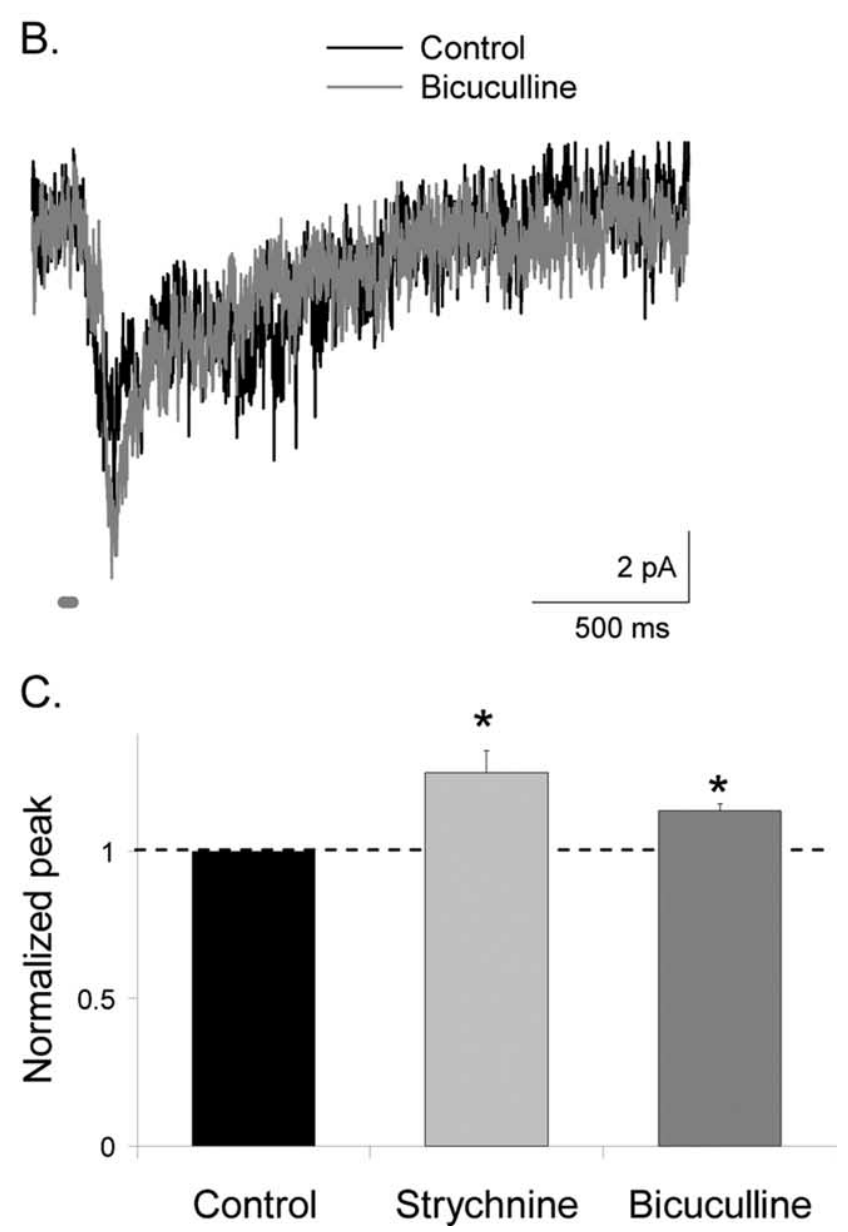

Figure 4. Presynaptic glycine and $\mathrm{GABA}_{A}$ receptors decrease the peak response of L-EPSCS from A17 amacrine cells. $A$, The peak amplitude of L-EPSCs ( $30 \mathrm{~ms}$ light stimulus; dark gray bar) from $A 17$ amacrine cells from $G A B A_{c} R$ null mice was increased by the addition of strychnine to block glycine receptors, but the decay time of the response was unaffected. $\boldsymbol{B}$, Similarly, the peak amplitude of L-EPSCs from $A 17$ amacrine cells from $G A B A_{C} R$ null mice was increased by addition of bicuculline to block $G A B A_{A}$ receptors, but the response decay was unaffected. $C$, The amplitude of L-EPSCs was significantly larger with the addition of both strychnine $\left({ }^{*} p<0.05\right)$ and bicuculline $\left({ }^{*} p<0.05\right)$. Peak values in bicuculline and strychnine are normalized to control values, represented by the dotted line.

ties of pharmacologically isolated $\mathrm{GABA}_{\mathrm{A}}$, glycine, and $\mathrm{GABA}_{\mathrm{C}}$ receptor-mediated sIPSCs, which are not affected by transmitter release properties. Figure 5 shows examples of temporally distinct glycine, $\mathrm{GABA}_{\mathrm{A}}$, and $\mathrm{GABA}_{\mathrm{C}}$ receptor-mediated sIPSCs. Glycine 
receptor-mediated sIPSCs (Fig. 5A) had an average peak amplitude of $10.14 \pm 0.35$ $\mathrm{pA}(n=193)$ and an average $\tau_{\text {decay }}$ of $3.62 \pm 0.1 \mathrm{~ms}$, which are shown in the distribution of $\tau_{\text {decay }}$ values and inset average in the right panel. $\mathrm{GABA}_{\mathrm{A}}$ receptormediated sIPSCs (Fig. 5B) had an average peak amplitude of $6.24 \pm 0.08 \mathrm{pA}(n=$ $972)$ and an average $\tau_{\text {decay }}$ of $1.98 \pm 0.1 \mathrm{~ms}$, which are shown in the distribution of $\tau_{\text {decay }}$ values and inset average in the right panel. The glycine receptor-mediated sIPSCs had larger amplitudes than the $\mathrm{GABA}_{\mathrm{A}}$ sIPSCs $\left(\mathrm{K}-\mathrm{S}\right.$, glycine vs $\mathrm{GABA}_{\mathrm{A}}$, $p<0.0001$ ) (Fig. 5, insets).

$\mathrm{GABA}_{\mathrm{C}}$ receptor-mediated sIPSCs were difficult to observe, as reported previously (Frech and Backus, 2004). However, in WT mice, we observed slow discrete events and an increase in tonic current after the addition of kainate (10 $\mu \mathrm{M})$ to the bath solution, along with strychnine and bicuculline. TPMPA blocked both the individual events and the tonic current, indicating that they were mediated by $\mathrm{GABA}_{\mathrm{C}}$ receptors. $\mathrm{GABA}_{\mathrm{C}}$ receptor-mediated, kainate-activated sIPSCs (Fig. 5C) had an average peak amplitude of $5.7 \pm 0.2 \mathrm{pA}(n=157)$. The $\mathrm{GABA}_{\mathrm{C}}$ receptor-mediated events were smaller in amplitude than the glycine receptor-mediated events $(\mathrm{K}-\mathrm{S}$, glycine vs $\mathrm{GABA}_{\mathrm{C}}, p<0.0001$ ) (Fig. 5, insets) but similar in amplitude to the $\mathrm{GABA}_{\mathrm{A}}$ sIPSCs. Because $G_{A B A}$ receptors have a smaller single-channel conductance than $\mathrm{GABA}_{\mathrm{A}}$ receptors, this suggests that more $\mathrm{GABA}_{C}$ receptors mediate sIPSCs than $\mathrm{GABA}_{\mathrm{A}}$ receptors (Qian and Dowling, 1995). $\mathrm{GABA}_{\mathrm{C}}$ receptor-mediated sIPSCs had an average $\tau_{\text {decay }}$ of $34.1 \pm 2.0 \mathrm{~ms}$, shown in the distribution of $\tau_{\text {decay }}$ values and inset average in the right panel of Figure 5C.

Comparisons of the normalized sIPSCs mediated by three receptor types in Figure $5 D$ and the distributions of decay times in Figure $5 A-C$ shows that $\mathrm{GABA}_{\mathrm{C}}$ receptormediated sIPSCs had the slowest decay time, followed by the rapidly decaying glycine receptor-mediated sIPSCs (K-S vs $\mathrm{GABA}_{\mathrm{C}}, p<0.0001$ ) and the more rapidly decaying $\mathrm{GABA}_{\mathrm{A}}$ receptor-mediated sIPSCs (K-S vs GABA $_{\mathrm{C}}$ and glycine, $p<$ $0.0001)$. Figure $5 D$ also shows the differences in the rising phase of the currents mediated by the three receptor types. $\mathrm{GABA}_{\mathrm{C}}$ receptor-mediated sIPSCs had significantly longer rise times $(7.2 \pm 0.5$ $\mathrm{ms} ; p<0.001)$ than glycine $(1.02 \pm 0.03$ $\mathrm{ms})$ and $\mathrm{GABA}_{\mathrm{A}}(1.03 \pm 0.03 \mathrm{~ms})$. Our results suggest that these receptors mediate distinct temporal components of rod bipolar cell inhibition at near physiologi-

\section{A. Glycine sIPSCs}
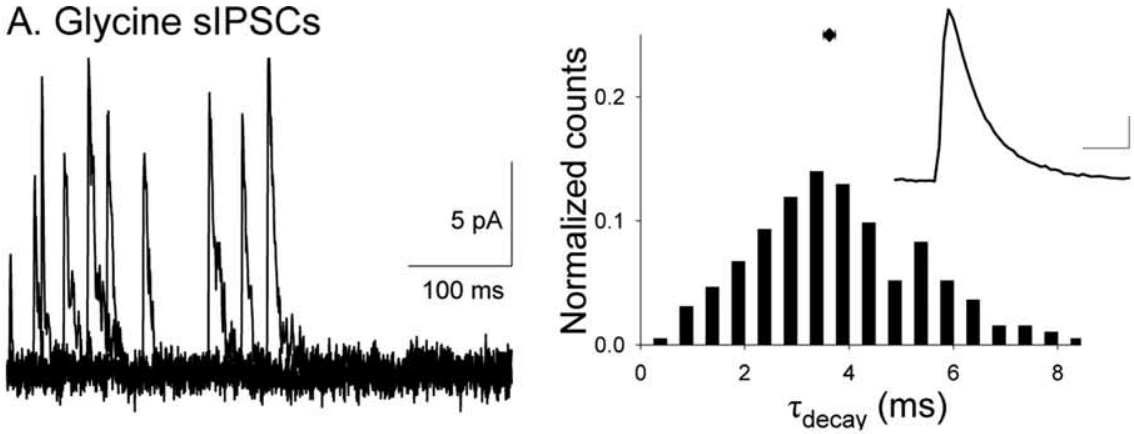

\section{B. $\mathrm{GABA}_{\mathrm{A}}$ sIPSCs}
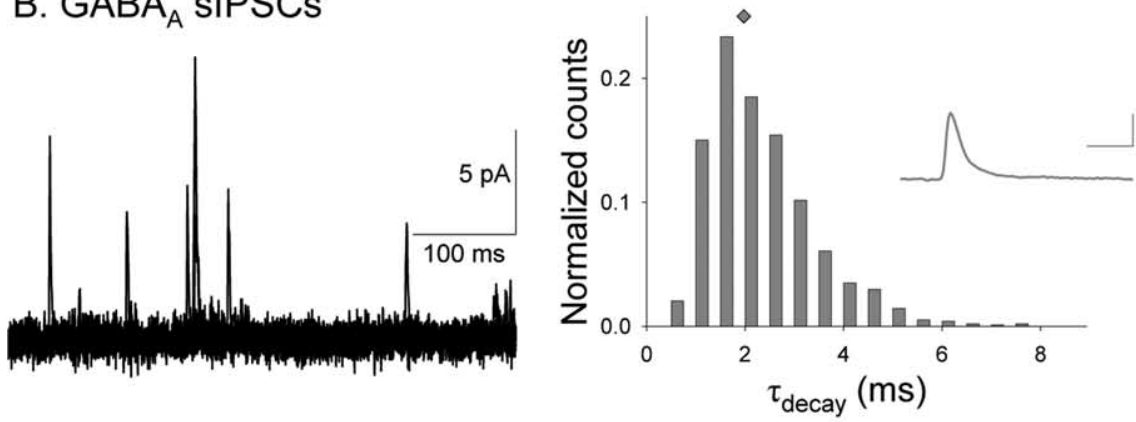

\section{GABA $_{C}$ IPSCs (Kainate activated)}
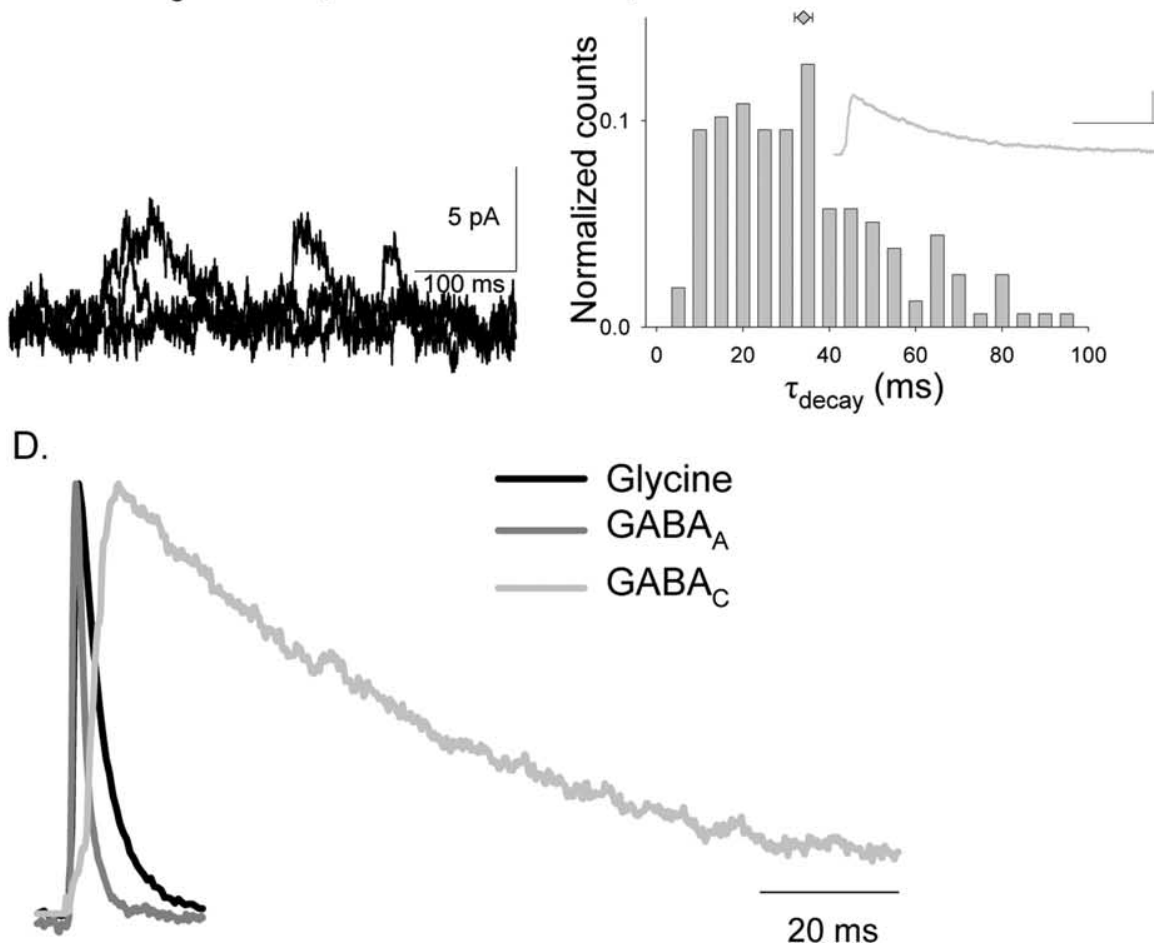

Figure 5. Glycine, $\mathrm{GABA}_{\mathrm{A}}$, and $\mathrm{GABA}_{\mathrm{C}}$ receptors mediate sIPSCs with distinct kinetics in rod bipolar cells. $\boldsymbol{A}$, Examples of isolated glycine receptor sIPSCs that were measured in the presence of bicuculline and TPMPA (left). The $\tau_{\text {decay }}$ histogram distribution (normalized to the total number of events) for all glycine receptor-mediated sIPSCs recorded are shown in the right, and the inset shows the average glycine receptor-mediated sIPSC. Calibration: $2 \mathrm{pA}, 5 \mathrm{~ms}$. $\boldsymbol{B}$, Examples of isolated $\mathrm{GABA}_{\mathrm{A}}$ receptor sIPSCS that were measured in the presence of strychnine and TPMPA (left). The normalized $\tau_{\text {decay }}$ histogram distribution for all GABA receptor-mediated sIPSCs recorded are shown in the right, and the inset shows the average $G_{A B A_{A}}$ receptor-mediated sIPSC. Calibration: $2 \mathrm{pA}, 5 \mathrm{~ms}$. GABA $\mathrm{A}$ receptor-mediated sIPSCs had a significantly shorter $\tau_{\text {decay }}$ than glycine receptor-mediated sIPSCS $(K-S, p<0.0001)$. C, Examples of isolated GABA receptor sIPSCS, measured in the presence of kainate, strychnine, and bicuculline (left). The normalized $\tau_{\text {decay }}$ histogram distribution for all GABA $\mathrm{C}_{C}$ receptor-mediated sIPSCs recorded is shown in the right, and the inset shows the average $G_{A B A}$ receptor-mediated sIPSC. Calibration: $2 \mathrm{pA}, 50 \mathrm{~ms}$. GABA ${ }_{C}$ receptor-mediated sIPSCs had a significantly longer $\tau_{\text {decay }}$ than glycine $(K-S, p<0.0001)$ and $G_{A B A}(K-S, p<0.0001)$ receptor-mediated sIPSC . D, Average normalized sIPSCs mediated by glycine, $G_{A B A}$, and $G A B A_{C}$ receptors. $G_{A B A}$ receptor-mediated sIPSCs have the longest decay time. 

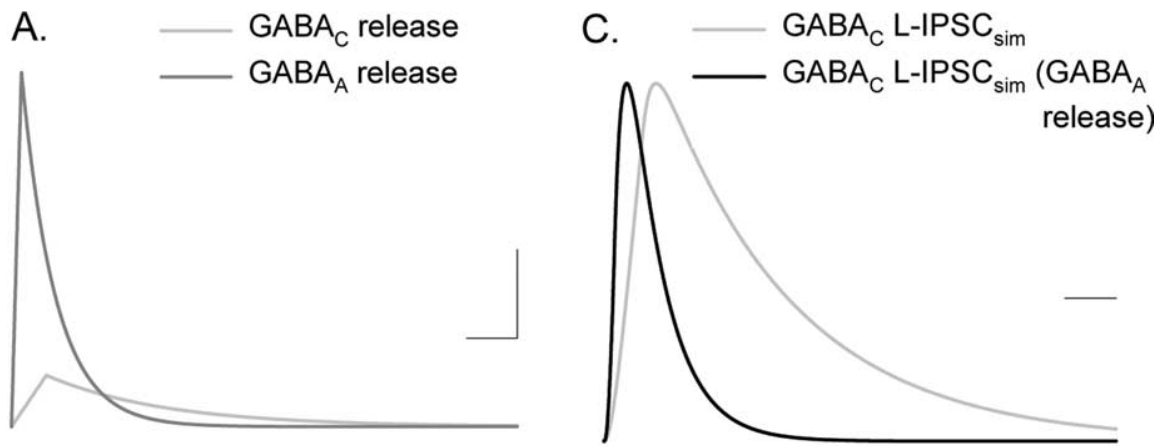

B.

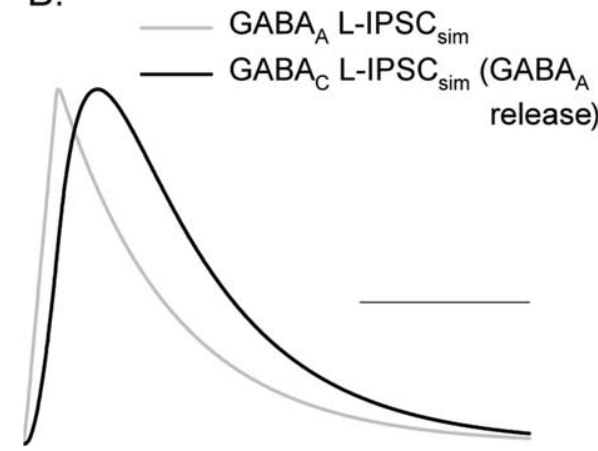

D.

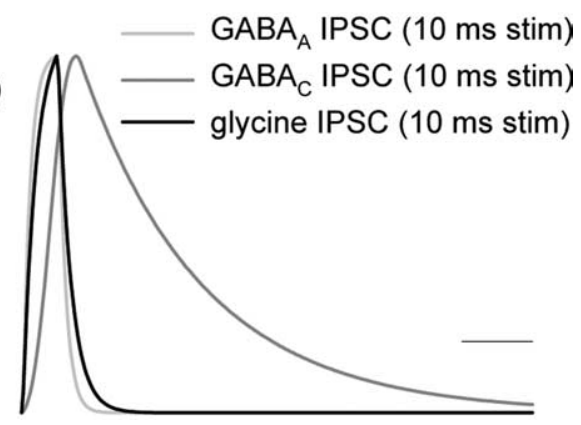

Figure 6. $G_{A B A}$ and $G A B A_{C}$ receptor-mediated L-IPSC s have distinct apparent release functions and receptor kinetics, both of which contribute to L-IPSC kinetics. $\boldsymbol{A}$, Release functions computed by deconvolving idealized $G A B A_{A}$ and $G_{C A B A}$ receptormediated L-IPSCs (supplemental data, available at www.jneurosci.org as supplemental material). GABA ${ }_{A}$ receptor-mediated L-IPSCS have a much larger release function than $G_{A B A}$ receptors, likely because of the much smaller $Q$ of $G A B A_{A}$ sIPSCS versus $\mathrm{GABA}_{C}$ sIPSCs. The $\mathrm{GABA}_{C}$ release function has a prolonged tail not shown by the $\mathrm{GABA}_{\mathrm{A}}$ release function. Calibration: 0.05 quanta/ms, 200 ms. $B$, To determine how much of the difference between $G_{A B A_{A}}$ and $G A B A_{C} L$-IPSC kinetics was attributable to receptor properties, we used the $G_{A B A_{A}}$ calculated release function to simulate L-IPSC s with the $G A B A_{A}$ and $G A B A_{C}$ sIPSCs. Shown is the normalized $G A B A_{C} L-I P S C$, using the $G A B A_{A}$ release function, that had a slower rise and decay time than the normalized $G_{A B A_{A}}$ L-IPSC, as a result of the slower kinetics of the GABA $C$ SIPSCS. The L-IPSC simulated with the GABA $A_{A}$ release function and SIPSC matched the properties of the average $G_{A B A_{A}}$ L-IPSC from Table 1. Calibration, $200 \mathrm{~ms}$. C, Shown are the normalized GABA $C$ L-IPSCs using the calculated $G_{A B A_{A}}$ and $G_{A B A}$ release rates. The prolonged tail of the estimated $G A B A_{C}$ release rate slows the kinetics of the GABA $\mathrm{C}_{C}$-IPSCS. Again, the L-IPSC simulated with the $\mathrm{GABA}_{C}$ release function and sIPSC matched the properties of the average $G_{A B A} L$-IPSC from Table 1. Calibration, $200 \mathrm{~ms}$. D, If GABA $A_{A}, G A B A_{C}$, and glycine receptor sIPSCs are activated by a brief (square wave, lasting $10 \mathrm{~ms}$ ) burst of neurotransmitter, then the distinct receptor properties filter the response, as shown by these normalized responses. Calibration, $200 \mathrm{~ms}$.

cal temperatures, consistent with the observations of previous studies on evoked $\mathrm{GABA}_{\mathrm{A}}, \mathrm{GABA}_{\mathrm{C}}$, and glycine receptormediated IPSCs at room temperature (Cui et al., 2003; Frech and Backus, 2004).

\section{Neurotransmitter release properties also determine L-IPSC time course}

The similarities between the time courses of glycine, $\mathrm{GABA}_{\mathrm{A}}$, and $\mathrm{GABA}_{\mathrm{C}}$ receptor-mediated sIPSCs and L-IPSCs suggest that receptor properties shaped the evoked responses. This idea is supported by our findings that eliminating $\mathrm{GABA}_{\mathrm{C}}$ receptors speeds the decays of L-IPSCs (Fig. 1), suggesting that slow $\mathrm{GABA}_{\mathrm{C}}$ receptors determine the decay of L-IPSCs. However, these observed differences may not be attributable to receptor properties alone because neurotransmitter release may differ for the inputs to specific receptor types. Although GABA and glycine release are most likely from distinct amacrine cells, it is not known whether $\mathrm{GABA}_{\mathrm{A}}$ and $\mathrm{GABA}_{\mathrm{C}}$ receptors, which are clustered at distinct synapses (Koulen et al., 1996), receive common or separate amacrine cell inputs.

L-IPSCs are made up of quantal events that reflect the activation of synaptic receptors by a vesicle of neurotransmitter. If these quantal events sum linearly, then the L-IPSC is the convolution of the sIPSC waveform and the neurotransmitter release time course (Cohen et al., 1981). Thus, deconvolution analysis can be used to estimate the neurotransmitter release underlying an evoked current (Van der Kloot, 1988; Diamond and Jahr, 1995). If receptors at synapses are saturated or desensitized during evoked release, or spillover occurs between synapses, then the estimated release may be an underestimate (saturation and desensitization) or overestimate (spillover) of the actual neurotransmitter released (Sargent et al., 2005). However, this "apparent release function" will reflect the neurotransmitter release necessary to produce the evoked response recorded and may also provide information about the factors that influence these currents (e.g., receptor saturation and spillover).

Therefore, to determine whether inhibitory receptors are activated by distinct transmitter release time courses, we estimated the transmitter release time courses that mediated glycine, $\mathrm{GABA}_{\mathrm{A}}$, and $\mathrm{GABA}_{\mathrm{C}}$ receptor-mediated L-IPSCs by deconvolving L-IPSCs and sIPSCs, mediated by each receptor subtype (see Materials and Methods, Eq. 2). Because deconvolution analysis requires a low noise signal, we used computed sIPSCs and L-IPSCs reflecting the average values measured for each receptor type instead of the raw data (see Methods and Methods) (Table 1) (supplemental Fig. S1 $A, B$, available at www.jneurosci.org as supplemental material). The calculated release function for the $\mathrm{GABA}_{\mathrm{A}} \mathrm{R}$-mediated L-IPSC had a larger amplitude and more rapid decay compared with that estimated for the $\mathrm{GABA}_{\mathrm{C}} \mathrm{R}$-mediated L-IPSC (Fig. 6A). The differences in release magnitude were likely attributable to $\mathrm{GABA}_{\mathrm{A}}$ and $\mathrm{GABA}_{\mathrm{C}}$ receptor properties. Fewer large sIPSCs comprised the $\mathrm{GABA}_{C}$ receptor-mediated L-IPSCs compared with $\mathrm{GABA}_{\mathrm{A}} \mathrm{R}$-mediated L-IPSCs. It is also possible that the high sensitivity $\mathrm{GABA}_{\mathrm{C}}$ receptors (Amin and Weiss, 1994) were saturated and unable to respond to additional neurotransmitter release. Additionally, the $\mathrm{GABA}_{\mathrm{C}}$ receptor release function showed a prolonged tail that was not observed in $\mathrm{GABA}_{\mathrm{A}}$ receptor release function, which could contribute to longer-lasting L-IPSCs mediated by $\mathrm{GABA}_{\mathrm{C}}$ receptors. Because this tail of neurotransmitter release is small and prolonged, it could reflect the spillover activation of $\mathrm{GABA}_{\mathrm{C}}$ receptors that has been reported in salamander bipolar cells (Ichinose and Lukasiewicz, 2002). A similar tail of release has been attributed to spillover onto AMPA receptors at the mossy fiber-granule cell synapse (Sargent et al., 2005).

These distinct apparent release time courses suggest that either $\mathrm{GABA}_{\mathrm{A}}$ and $\mathrm{GABA}_{\mathrm{C}}$ receptors receive different inputs or they receive a common input but their distinct receptor properties, such as saturation and spillover activation, distort the release estimates. If $\mathrm{GABA}_{\mathrm{C}}$ and $\mathrm{GABA}_{\mathrm{A}}$ receptors are activated by the 
same GABA release function, then receptor kinetics should also shape L-IPSCs. To test whether receptor kinetics contributed to L-IPSC time courses, we simulated $\mathrm{GABA}_{\mathrm{A}}$ and $\mathrm{GABA}_{\mathrm{C}}$ receptor-mediated L-IPSCs by convolving each sIPSC waveform, which reflects distinct receptor kinetics (Fig. 5), with the same release function (Eq. 1), computed from $\mathrm{GABA}_{\mathrm{A}} \mathrm{R}$-mediated L-IPSCs (Fig. 6B). The normalized, simulated $\mathrm{GABA}_{\mathrm{C}} \mathrm{R}$ mediated

L-IPSC was significantly slower than the $\mathrm{GABA}_{\mathrm{A}} \mathrm{R}$-mediated L-IPSC (half-width, 180 vs $116 \mathrm{~ms}$ ), demonstrating that receptor properties shaped the L-IPSCs when evoked by the same release function. However, the differences between $\mathrm{GABA}_{C}$ and $\mathrm{GABA}_{\mathrm{A}}$ receptor-mediated simulated L-IPSCs were significantly smaller than the more than threefold difference in decay time seen in recorded $\mathrm{GABA}_{\mathrm{A}}$ and $\mathrm{GABA}_{\mathrm{C}}$ receptor-mediated L-IPSCs (compare Figs. $6 B, 2 A 1$; Table 1), suggesting that differences in receptor kinetics cannot account for these differences when the release time course is similar. To determine how release time course shaped L-IPSCs, we compared the L-IPSCs obtained by convolving the $\mathrm{GABA}_{C} \mathrm{R}$ mediated sIPSC with the different release time courses sensed by $\mathrm{GABA}_{\mathrm{A}}$ and $\mathrm{GABA}_{\mathrm{C}}$ receptors. Using the $\mathrm{GABA}_{\mathrm{C}} \mathrm{R}$ release function, which contained the prolonged tail of release (Fig. $6 A$ ), the normalized simulated $\mathrm{GABA}_{C}$ L-IPSC (Fig. $6 C$, gray trace) was significantly slower (half-width of $459 \mathrm{~ms}$ ) than normalized L-IPSC obtained using the faster $\mathrm{GABA}_{\mathrm{A}}$ release function (halfwidth of $180 \mathrm{~ms}$ ) (black trace). Similar comparisons of the factors that shape $\mathrm{GABA}_{\mathrm{A}}$ and glycine receptor-mediated L-IPSCs suggested that both release and receptors properties contribute to the kinetics of these L-IPSCs (supplemental Fig. S1C, available at www.jneurosci.org as supplemental material).

The roles of receptor properties in shaping L-IPSCs may be obscured by the asynchronous nature of light-evoked transmitter release, given that the L-IPSC durations were much longer than the $30 \mathrm{~ms}$ light stimulus (Fig. 6A) (supplemental Fig. S1C, available at www.jneurosci.org as supplemental material). To better determine how receptor properties might shape L-IPSCs, we convolved the sIPSCs with an idealized $10 \mathrm{~ms}$, synchronous release function. When release was synchronous, even more dramatic differences between glycine, $\mathrm{GABA}_{\mathrm{A}}$, and $\mathrm{GABA}_{\mathrm{C}}$ receptormediated simulated L-IPSCs became apparent (Fig. 6D). These findings suggest that, when release is more synchronous, receptor properties play a larger role in shaping L-IPSCs.

\section{$\mathrm{GABA}_{\mathrm{C}}$ receptor-mediated L-IPSCs are selectively enhanced by increased spillover}

Our simulations suggest that there are differences in the neurotransmitter release that are sensed by $\mathrm{GABA}_{\mathrm{A}}$ and $\mathrm{GABA}_{\mathrm{C}}$ receptors (Fig. 6A). A possible explanation for the more prolonged release sensed by $\mathrm{GABA}_{C}$ receptors is that GABA spills over from neighboring synapses activating the higher sensitivity $\mathrm{GABA}_{C}$ receptors, as reported for glutamate currents receptors in the cerebellum (Sargent et al., 2005). If spillover selectively activates $\mathrm{GABA}_{\mathrm{C}}$ receptors, then increasing spillover by blocking GABA uptake with NO-711 should enhance $\mathrm{GABA}_{\mathrm{C}}$ but not $\mathrm{GABA}_{\mathrm{A}}$ receptor-mediated L-IPSCs. Figure 7 shows that NO-711 $(5 \mu \mathrm{M})$ enhanced $\mathrm{GABA}_{\mathrm{C}}$ receptor-mediated L-IPSCs (98.8 $\pm 31.7 \%$; $p<0.05$; $n=6$ ) (Fig. 7C) but did not enhance $\mathrm{GABA}_{\mathrm{A}}$ receptormediated L-IPSCs (13.2 $\pm 3.2 \%$ decrease; $p<0.01 ; n=6)$, suggesting that spillover only activated $\mathrm{GABA}_{\mathrm{C}}$ receptors. NO711 also prolonged the decay $\left(D_{37}\right)$ of $\mathrm{GABA}_{\mathrm{C}}$ receptors by $15.3 \pm$ $2.4 \%(p<0.01)$ (Fig. $7 D)$ but left the $\mathrm{GABA}_{\mathrm{A}} D_{37}$ unchanged $(11.1 \pm 8.6 \%$ decrease; NS, $p=0.3)$, consistent with the spillover activation of $\mathrm{GABA}_{\mathrm{C}}$ receptors. Together, these results suggest that GABA spillover between synapses prolonged the time course and enhanced the magnitude of $\mathrm{GABA}_{\mathrm{C}}$ receptor-mediated L-IPSCs.

\section{Increased $\mathrm{GABA}$ release preferentially activates \\ $\mathrm{GABA}_{\mathrm{C}}$ receptors}

If spillover of GABA preferentially activates $\mathrm{GABA}_{\mathrm{C}}$ receptors, then we would expect that increasing GABA release would selectively increase $\mathrm{GABA}_{\mathrm{C}}$ receptor-mediated currents. We tested how the $\mathrm{GABA}_{\mathrm{C}} \mathrm{R}$ contribution to the L-IPSCs changed with enhanced neurotransmitter release by increasing the intensity of the light stimulus. Because the L-IPSC decay is determined by $\mathrm{GABA}_{\mathrm{C}}$ receptors, we compared the $D_{37}$ for L-IPSCs evoked by different light intensities ( $30 \mathrm{~ms}$ duration) in $\mathrm{GABA}_{\mathrm{C}} \mathrm{R}$ null and WT mice. In both WT (Fig. $8 A$ ) and GABA $_{C}$ R null (Fig. $8 B$ ) mice, the $D_{37}$ values increased as a function of light intensity (Fig. $8 C)$. Except for the dimmest intensity, the WT L-IPSCs $(n=10)$ were always significantly more prolonged than the $\mathrm{GABA}_{\mathrm{C}} \mathrm{R}$ null L-IPSCs $(p<0.01 ; n=6)$. The maximum decay observed in $\mathrm{GABA}_{\mathrm{C}} \mathrm{R}$ null mice was only $35 \%$ of the maximum decay in WT mice $(p<0.05)$, reflecting the absence of $\mathrm{GABA}_{\mathrm{C}}$ receptors. The dynamic ranges $\left(L_{20-80}\right.$, the intensity range for $20-80 \%$ of maximal $D_{37}$ ) were similar in WT and $\mathrm{GABA}_{\mathrm{C}} \mathrm{R}$ null mice (WT, $2.1 \pm$ 0.8 ; null, $2.4 \pm 0.8 ; p=0.8)$, but the light sensitivity $\left(L_{50}\right.$, intensity for half-maximal $D_{37}$ ) was reduced in mice that lacked $\mathrm{GABA}_{\mathrm{C}}$ 


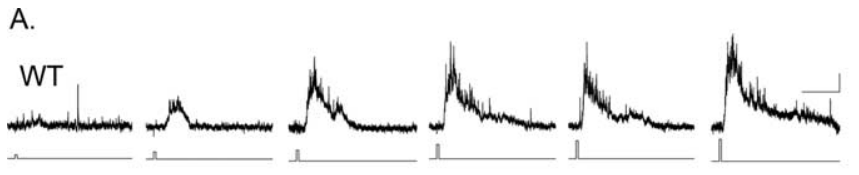

B. $\mathrm{GABA}_{C} \mathrm{R}$ Null

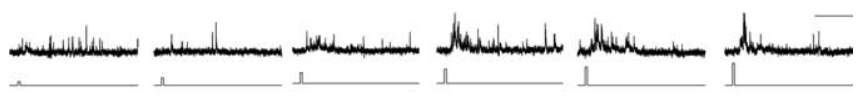

C.

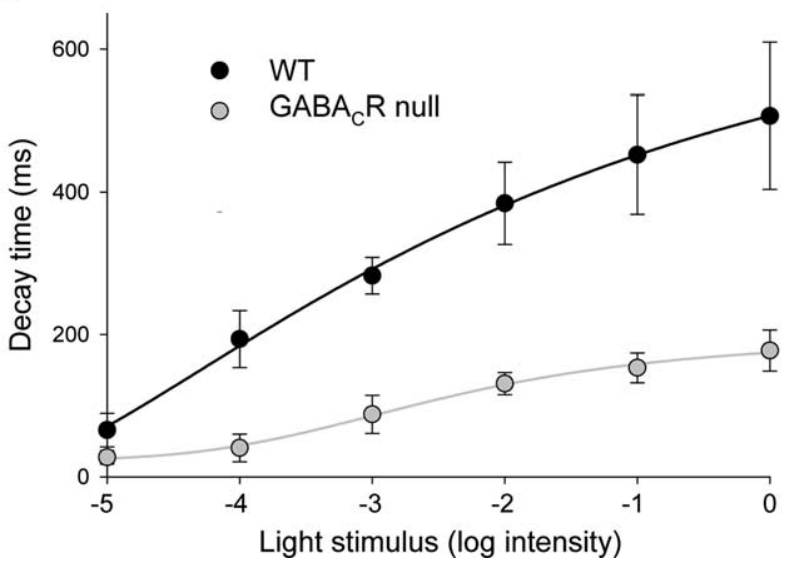

Figure 8. Eliminating $G_{A B A}$ receptors reduced the decay time of rod bipolar cell L-IPSCS as a function of light intensity. $A$, L-IPSCS from a WT rod bipolar cell in response to increasing intensities of light ( $30 \mathrm{~ms}$ light stimulus). Calibration: 5 pA, $500 \mathrm{~ms}$. $B$, L-IPSCs from a GABA $R$ null rod bipolar cell in response to increasing intensities of light. The increases in the magnitude and decay of the response are smaller for the $G A B A_{C} R$ null mice. $C$, The average L-IPSC $D_{37}$ values from WT $(n=10)$ and $\mathrm{GABA}_{C} R$ null $(n=6)$ mice are plotted as a function of light intensity (log relative intensity). The curves are the best fits to a logistic function. The maximum $D_{37}$ of the $\mathrm{GABA}_{C} R$ null curve was $35 \%$ of the WT maximum. The $L_{20-80}$ values of the fits were not significantly changed (WT, $2.1 \pm 0.8$; null, $2.4 \pm 0.8$ ), but the $\mathrm{GABA}_{C} \mathrm{R}$ null curve had a lower $\mathrm{EC}_{50}$ (WT, $-3.4 \pm 0.2$; null, $-2.7 \pm 0.2$ ).

receptors $\left(L_{50} \mathrm{WT},-3.4 \pm 0.2 ; L_{50}\right.$ null, $\left.-2.7 \pm 0.2 ; p<0.05\right)$. The reduced light sensitivity in $\mathrm{GABA}_{\mathrm{C}} \mathrm{R}$ null mice is consistent with the notion that $\mathrm{GABA}_{\mathrm{C}}$ receptors are more sensitive to GABA than $\mathrm{GABA}_{\mathrm{A}}$ receptors (Qian and Dowling, 1993; Amin and Weiss, 1994; Feigenspan and Bormann, 1994). Our results show that stronger light stimuli resulted in more prolonged responses that were attributable to the activation of $\mathrm{GABA}_{\mathrm{C}}$ receptors to a greater extent than $\mathrm{GABA}_{\mathrm{A}}$ and glycine receptors. This suggests that stronger stimuli increase the probability of GABA release that results in the preferential activation of $\mathrm{GABA}_{\mathrm{C}}$ receptors, attributable, in part, to spillover transmission (Fig. 7).

\section{$\mathrm{GABA}_{\mathrm{C}}$ receptors are poor temporal encoders of inhibition}

We have shown that both receptor and release properties can shape L-IPSCs evoked by brief stimuli, but how do these properties shape L-IPSCs evoked by more prolonged light stimuli? Because $\mathrm{GABA}_{\mathrm{C}}$ receptors respond sluggishly to brief spontaneous and light-evoked GABA release, they are poor sensors of temporal changes in synaptic GABA concentration. In contrast, $\mathrm{GABA}_{\mathrm{A}}$ and glycine receptors, which respond briskly to brief, spontaneous GABA release, are better sensors of temporal changes of inhibitory inputs. Also, $\mathrm{GABA}_{\mathrm{C}}$ receptors are more sensitive to GABA (Amin and Weiss, 1994) and unbind GABA slowly (Chang and Weiss, 1999), suggesting that they may be saturated and ill equipped to resolve a brief light stimulus. Given these limitations of $\mathrm{GABA}_{\mathrm{C}} \mathrm{R}$-mediated signaling, responses to more prolonged stimuli may not differ substantially from those to briefer stimuli.

To test how $\mathrm{GABA}_{\mathrm{C}}$ receptor contributions vary with light stimulus duration, we compared L-IPSCs evoked by brief (10 ms) and prolonged (1000 ms) stimuli from WT and $\mathrm{GABA}_{\mathrm{C}} \mathrm{R}$ null mice. For brief stimuli, $\mathrm{GABA}_{\mathrm{C}}$ receptors determine the duration of the L-IPSC, as shown by comparing the prolonged L-IPSC recorded from WT mice (Fig. 9A, gray trace) with the shorter L-IPSC recorded from $\mathrm{GABA}_{\mathrm{C}} \mathrm{R}$ null mice (Fig. $9 B$, gray trace). When the stimulus was increased to $1000 \mathrm{~ms}$, the L-IPSC charge transfer in WT mice (Fig. 9A) was only marginally increased $(173 \pm 12 \% ; n=12)$. However, responses in $\mathrm{GABA}_{\mathrm{C}} \mathrm{R}$ null mice (Fig. $9 B$ ) were dramatically increased, compared with WT mice $\left(414 \pm 73 \%\right.$ of the 10 ms stimulus; WT vs GABA $_{\mathrm{C}}$ R null, $p<0.01$; $n=7$ ) (Fig. 9C). These data suggest that the lower sensitivity to changes in stimulus duration in WT mice was attributable to slow temporal response properties and/or saturation of $\mathrm{GABA}_{\mathrm{C}}$ receptors. The enhanced sensitivity to changes in stimulus duration observed in $\mathrm{GABA}_{\mathrm{C}} \mathrm{R}$ null mice reflects the faster, temporally responding $\mathrm{GABA}_{\mathrm{A}}$ and glycine receptor abilities to respond with better fidelity to changes in transmitter release.

\section{Distinct inhibitory inputs to rod bipolar cells affect different aspects of glutamate release}

How is glutamate release affected when the L-IPSCs are altered by lengthening the light stimulus? Because excitatory inputs to rod bipolar cells increase with light stimulus duration (Berntson et al., 2004; Pang et al., 2004), glutamate release is likely to increase with increased stimulus duration. However, the glutamate release from rod bipolar cells is also shaped by presynaptic inhibitory inputs, which may change with brief and prolonged light stimuli. We assessed how these two factors interact by recording L-EPSCs from A17 amacrine cells. Figure $10 \mathrm{~A}$ shows that, when the light stimulus duration was increased from 10 to $1000 \mathrm{~ms}$, the L-EPSC charge transfer in WT mice was increased to $248 \pm 7 \%$ of control $(n=7)$. When the stimulus duration was increased, both the excitatory output (Fig. 10A) and presynaptic inhibition (Fig. 9A) to rod bipolar cells were enhanced. In WT mice, the increase in L-EPSC charge transfer with stimulus duration demonstrates that glutamate release was enhanced, consistent with our findings (Fig. 9) that presynaptic inhibition was only modestly enhanced with increased stimulus duration.

To better understand how $\mathrm{GABA}_{\mathrm{C}}$ receptors control the duration of glutamate release, we tested the effects of light stimulus duration in mice that lacked $\mathrm{GABA}_{\mathrm{C}}$ receptors. As noted above, glutamate release is enhanced in $\mathrm{GABA}_{\mathrm{C}} \mathrm{R}$ null mice (Fig. 3). In addition, the magnitude of presynaptic inhibition is more sensitive to stimulus duration in $\mathrm{GABA}_{\mathrm{C}} \mathrm{R}$ null mice (Fig. 9), suggesting that inhibition evoked by prolonged stimuli will suppress glutamate release more, making release less sensitive to stimulus duration. Figure $10 \mathrm{~B}$ shows that increasing stimulus duration resulted in a smaller increase in L-EPSCs in $\mathrm{GABA}_{\mathrm{C}} \mathrm{R}$ null mice compared with WT mice ( $190 \pm 12 \% ; n=10$; WT vs null, $p<$ 0.01 ) (Fig. 10A). Together, our findings show that amacrine cell L-EPSCs reflect a balance between glutamate release and presynaptic inhibition. Presynaptic $\mathrm{GABA}_{\mathrm{C}}$ receptors limit glutamate release, but they also allow the magnitude of glutamate release to be more sensitive to increases in stimulus duration.

\section{Discussion}

$\mathrm{GABA}_{\mathrm{C}}, \mathrm{GABA}_{\mathrm{A}}$, and glycine receptor-mediated inputs to rod bipolar cell terminals differentially shape the time course of inhibition that modulates glutamate release. Slow $\mathrm{GABA}_{\mathrm{C}}$ receptor- 

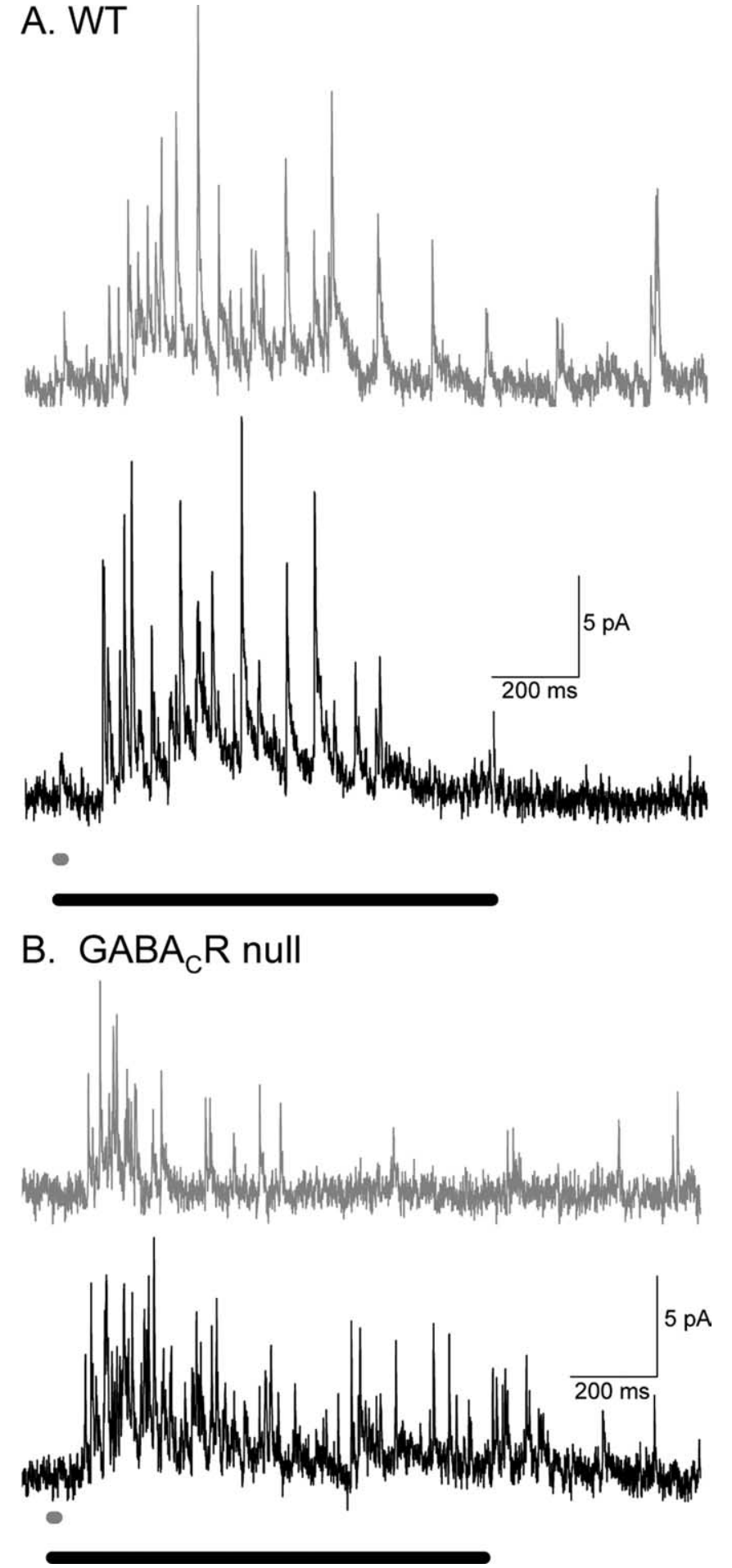

Figure 9. WT and $G A B A_{C} R$ null mice L-IPSCS respond differently to increasing light duration. A, Example L-IPSCs from WT rod bipolar cells in response to $10 \mathrm{~ms}$ (dark gray trace) and $1000 \mathrm{~ms}$ (black trace) light stimulation. The two L-IPSCs do not have drastically different charge transfers. $\boldsymbol{B}$, Example L-IPSCs from GABA $\mathrm{C}$ Rull rod bipolar cells in response to $10 \mathrm{~ms}$ (dark gray trace) and $1000 \mathrm{~ms}$ (black trace) light stimulation. The $10 \mathrm{~ms}$ L-IPSC is much smaller than that $1000 \mathrm{~ms}$ L-IPSC. GABA $R$ R null L-IPSCs increase significantly more when the light duration is increased $(p<0.01)$.

mediated inputs govern the extent of presynaptic inhibition, limiting the duration of glutamate release. In contrast, fast glycine and $\mathrm{GABA}_{\mathrm{A}}$ receptor-mediated inputs determine the initial peak magnitude of presynaptic inhibition, limiting the early phase of
A. WT

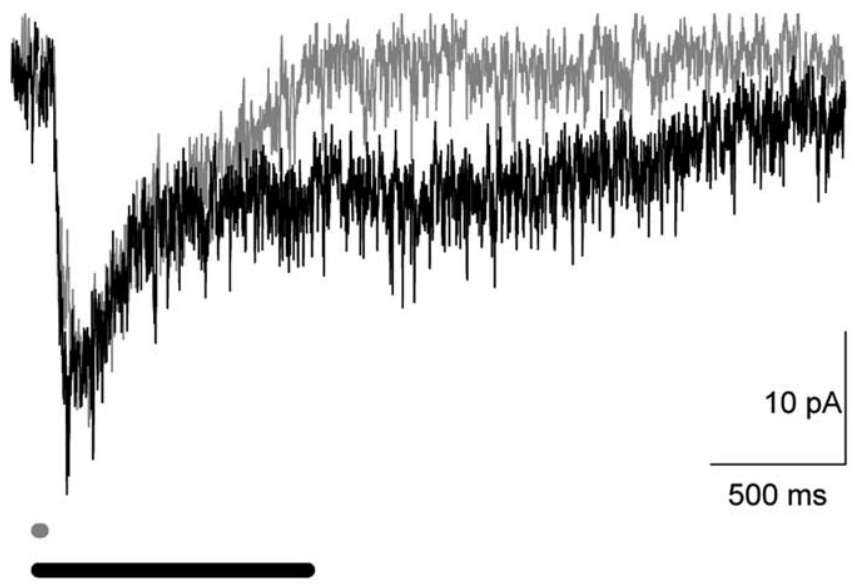

\section{B. $\mathrm{GABA}_{\mathrm{C}} \mathrm{R}$ null}

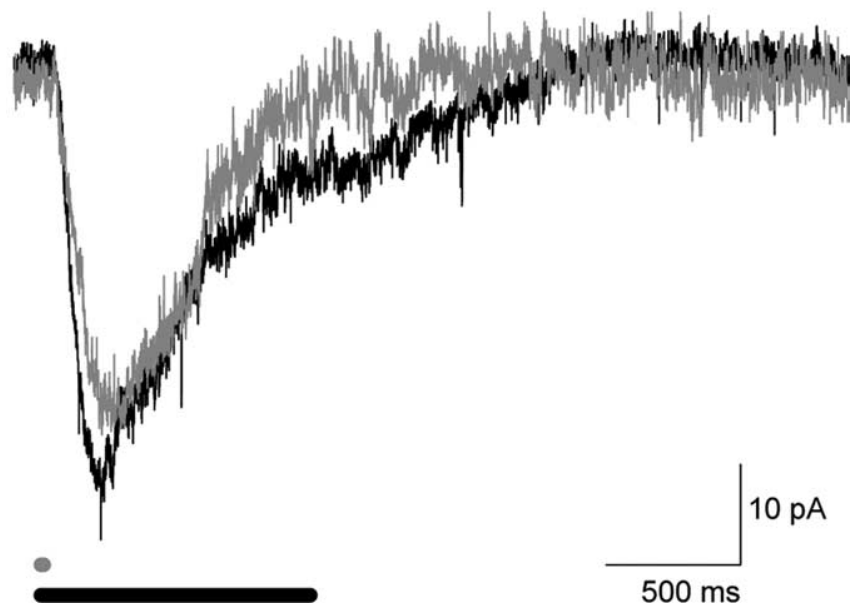

Figure 10. L-IPSCs differentially shape A17 L-EPSCs in WT and GABA $A_{C}$ Rnull mice. $A$, Example L-EPSCs from WT A17 amacrine cells in response to $10 \mathrm{~ms}$ (dark gray traces) and $1000 \mathrm{~ms}$ (black traces) light stimulation. The $10 \mathrm{~ms}$ L-EPSC is smaller than that $1000 \mathrm{~ms}$ L-EPSC. B, Example L-EPSCs from GABA ${ }_{C} R$ null $A 17$ amacrine cells in response to 10 and 1000 ms light stimulation. The two L-EPSCs do not have as large a difference in charge transfers as the WT L-EPSCS. WT L-EPSCs increase significantly more when the light duration is increased $(p<0.01)$.

glutamate release. These differences reflect differences in receptor properties, transmitter release, and spillover that shape individual inhibitory inputs.

\section{Receptor properties tune inhibition}

Our results suggest that several aspects of receptor properties contribute to temporal tuning of inhibition in the retina. sIPSCs, which solely reflect receptor properties, showed that glycine, $\mathrm{GABA}_{\mathrm{A}}$, and $\mathrm{GABA}_{\mathrm{C}}$ receptors have distinct kinetics, in agreement with previous reports (Euler and Wässle, 1998; Lukasiewicz and Shields, 1998; Shields et al., 2000; Frech and Backus, 2004; Vigh et al., 2005). Our data (Fig. 2) and simulations (Fig. 6) suggest that receptor kinetics determine part of the differences between L-IPSCs. Similar temporal tuning of inhibitory responses with distinct receptor types has been shown previously (Brickley et al., 1996; Hajos and Mody, 1997; Jonas et al., 1998; O'Brien and Berger, 1999; Hamann et al., 2002), but functional roles have not been assigned to these distinct inputs.

Receptor properties may also determine how L-IPSCs change with increasing stimulus duration. GABA and glycine rapidly un- 
bind from $\mathrm{GABA}_{\mathrm{A}}$ and glycine receptors (Amin and Weiss, 1994; Legendre, 1998), whereas $\mathrm{GABA}_{\mathrm{C}}$ receptors lock onto GABA, unbinding it slowly (Chang and Weiss, 1999). Additionally, $\mathrm{GABA}_{\mathrm{C}}$ receptors are 10 -fold more sensitive to GABA than $\mathrm{GABA}_{\mathrm{A}}$ receptors (Amin and Weiss, 1994) and are also more sensitive to GABA than glycine receptors are to glycine (Singer and Berger, 1999; Grudzinska et al., 2005). This prolonged, highaffinity binding of GABA could saturate $\mathrm{GABA}_{\mathrm{C}}$ receptors after a brief light stimulus, making them unresponsive to additional stimuli, unlike glycine and $\mathrm{GABA}_{\mathrm{A}}$ receptors. $\mathrm{GABA}_{\mathrm{C}}$ receptors show minimal desensitization (Amin and Weiss, 1994) compared with $\mathrm{GABA}_{\mathrm{A}}$ receptors and thus remain activated in the sustained presence of neurotransmitter. These $\mathrm{GABA}_{C}$ receptor properties allow them to be preferentially activated by increased spillover (Fig. 7) and increased light-evoked release (Fig. 8), as reported in salamander (Ichinose and Lukasiewicz, 2002). In other parts of the CNS, transient and more sustained inhibition are also mediated by distinct subtypes of $\mathrm{GABA}_{\mathrm{A}}$ receptors, which have similar differences in affinity for GABA and desensitization as $\mathrm{GABA}_{\mathrm{A}}$ and $\mathrm{GABA}_{\mathrm{C}}$ receptors (Brickley et al., 1996, 2001; Wei et al., 2003; Prenosil et al., 2006).

Spillover activation of $\mathrm{GABA}_{\mathrm{C}}$ receptors may shape L-IPSCs Spillover depends on the amount of neurotransmitter release (Diamond, 2001; Pankratov and Krishtal, 2003; Sola et al., 2004; Christie and Jahr, 2006), the efficacy of transmitter uptake (Chen and Diamond, 2002), and the presence of high-affinity receptors that respond to low levels of neurotransmitter (Rossi and Hamann, 1998; Diamond, 2001; Lozovaya et al., 2004). Consistent with the spillover activation, we show that the $\mathrm{GABA}_{\mathrm{C}}$ receptormediated component of L-IPSCs was enhanced and prolonged by reducing uptake (Fig. 7). Also, when uptake remained intact, there was a tail in the release time course sensed by $\mathrm{GABA}_{\mathrm{C}}$ receptors that was not observed with $\mathrm{GABA}_{\mathrm{A}}$ receptors (Fig. 6). Is this tail attributable to spillover?

To address this, we estimated whether the quantal content in the tail of release sensed by $\mathrm{GABA}_{\mathrm{C}}$ receptors was consistent with the magnitude of spillover observed at other synapses. We estimated the total number of released quanta from the area under the calculated release. From these areas (Fig. 6), we estimated that 31 quanta activated $\mathrm{GABA}_{\mathrm{A}}$ receptors and 16 quanta activated $\mathrm{GABA}_{\mathrm{C}}$ receptors, for a total of 47 quanta of GABA. The tail attributed to spillover and sensed by $\mathrm{GABA}_{\mathrm{C}}$ receptors represents six quanta or $\sim 13 \%$ of the total quantal content released at both $\mathrm{GABA}_{\mathrm{A}}$ - and $\mathrm{GABA}_{\mathrm{C}}$ receptor-containing synapses. Because synaptic $\mathrm{GABA}_{C}$ receptor may be saturated as a result of their high affinity for GABA (Amin and Weiss, 1994), the calculated, total quanta of GABA released may be an underestimate of the actual release, leading to an overestimate of the percentage of GABA release attributable to spillover. The extent of spillover has been estimated for glutamatergic synapses in hippocampus (Rusakov and Kullmann, 1998; Barbour, 2001). Although hippocampal and rod bipolar cell synapse densities are similar (two glutamate synapses per cubic micrometer and three $\mathrm{GABA}_{\mathrm{C}}$ synapses per cubic micrometer, respectively) (Fletcher et al., 1998; Rusakov and Kullmann, 1998), other factors that affect spillover likely vary in the two systems, such as transporter density and synaptic geometry. Although these caveats may influence the relative magnitudes of spillover, we find that estimates of transmission attributable to spillover are similar. At hippocampal synapses, glutamate spillover to NMDA receptors is estimated to range from 1.4 to $19 \%$ of the total release $(0.03-0.4 \%$ of glutamate per vesicle and 47 released vesicles, as in our calculations). The gen-
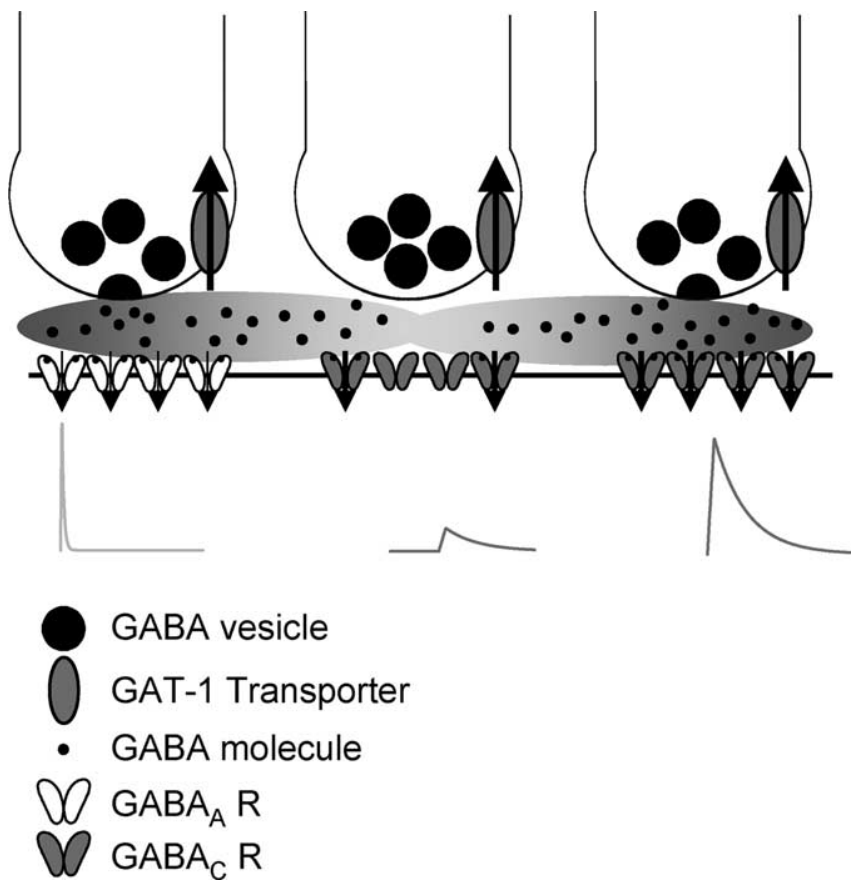

Figure 11. The properties of inhibitory synaptic transmission are controlled by many independent factors. Shown is an example of three amacrine cell terminals releasing GABA onto synapses on a bipolar cell. The terminal on the left is activating $G_{A B A_{A}}$ receptors that have a short time course, and the terminal on the right is activating $G A B A_{C}$ receptors that have a prolonged time course. The terminal in the middle has not released GABA, but the GABA receptors underlying it are being activated by spillover from neighboring synapses, which respond with a small, delayed current. GABA is taken up by GAT-1 transporters, which control the amount of GABA that leaves the synapse.

eral agreement between these estimates suggests that our spillover model is reasonable (Fig. 11) and predicts that spillover from both $\mathrm{GABA}_{\mathrm{A}}$ and $\mathrm{GABA}_{\mathrm{C}}$ receptor-containing synapses activate $\mathrm{GABA}_{\mathrm{C}}$ receptors at neighboring synapses.

\section{Transmitter release properties shape inhibition}

Our transmitter release estimates suggested that glycine, $\mathrm{GABA}_{\mathrm{A}}$, and $\mathrm{GABA}_{\mathrm{C}}$ receptor-mediated inputs were also shaped by distinct release time courses. However, as discussed above, distinct release time courses may reflect the differences between $\mathrm{GABA}_{\mathrm{A}}$ and $\mathrm{GABA}_{\mathrm{C}}$ receptor properties, such as saturation and spillover activation. Still, $\mathrm{GABA}_{\mathrm{A}}$ and $\mathrm{GABA}_{\mathrm{C}}$ receptors are clustered at distinct synapses (Fletcher et al., 1998; Koulen et al., 1998), suggesting that distinct release from separate inputs may occur, but it is not known whether these receptors receive input from the same or separate amacrine cells. Because glycine and GABA receptors are activated by release from distinct populations of amacrine cells (Pourcho and Goebel, 1983; Vaney, 1990; Menger et al., 1998), it is likely that the different release time courses we measured reflect activation by separate release transients. This adds another dimension of control into synaptic transmission. Similar differences in neurotransmitter release have been shown to mediate distinct response kinetics in many systems, including the hippocampus (Hefft and Jonas, 2005) and the photoreceptor to bipolar cell synapse (Cadetti et al., 2005).

\section{Roles of inhibition on signal processing}

The slow $\mathrm{GABA}_{\mathrm{C}}$ receptors that dominated rod bipolar L-IPSCs are well matched to the time course of rod bipolar cell excitation, which is significantly slower than the cone pathway excitation 
(Schnapf and Copenhagen, 1982; Cadetti et al., 2005). Prolonged $\mathrm{GABA}_{\mathrm{C}}$ receptor-mediated inhibition is optimized to control the slow glutamate release from rod bipolar cells, as suggested by a recent report on feedback inhibition in fish bipolar cells (Vigh et al., 2005). Similar matching of IPSC and EPSC time courses has been reported in development, because the kinetics of inhibitory currents (Brickley et al., 1996; Dunning et al., 1999; Okada et al., 2000) decrease in parallel with the kinetics of excitatory currents (Takahashi, 2005). Thus, a role of $\mathrm{GABA}_{\mathrm{C}}$ receptors may be to match inhibition to slow rod-mediated excitation.

Additionally, the distinct forms of light-evoked presynaptic inhibition mediated by $\mathrm{GABA}_{\mathrm{A}}, \mathrm{GABA}_{\mathrm{C}}$, and glycine receptors differentially shape excitatory signaling to $\mathrm{A} 17$ amacrine cells. We found that $\mathrm{GABA}_{\mathrm{C}}$ receptors limit glutamate release from rod bipolar cells most effectively, because L-EPSCs transferred more charge and were more prolonged in mice lacking $\mathrm{GABA}_{\mathrm{C}}$ receptors, in agreement with previous studies (Lukasiewicz et al., 1994; Dong and Werblin, 1998; Bloomfield and Xin, 2000). Similarly, our light stimulus duration results suggested that the limited increase of $\mathrm{GABA}_{C}$ receptor-mediated inhibition with stimulus duration serves to increase the temporal sensitivity of excitatory outputs of the retina. However, we also found that $G_{A B A}$ receptor-mediated inhibition was sensitive to changes in stimulus intensity, potentially compensating for the activation of more excitatory inputs with greater stimulus intensities. Thus, $\mathrm{GABA}_{\mathrm{C}}$ receptors played two roles: regulating the magnitude of glutamate release in response to brief stimuli and allowing the increase of glutamate release with increasing stimulus duration. Thus, $\mathrm{GABA}_{\mathrm{C}}$ receptors could be important in determining the timing and magnitude of excitatory signaling in the retina.

Although $\mathrm{GABA}_{\mathrm{A}}$ and glycine receptors transfer less charge than $\mathrm{GABA}_{\mathrm{C}}$ receptors in rod bipolar cells, our findings demonstrate that their more rapid response properties contributed to shaping the rod bipolar cell output by decreasing the initial peak of the A17 amacrine cell L-EPSCs. A larger amacrine cell L-EPSC peak suggests that it will reach its spike threshold faster, speeding its communication with downstream neurons. Consequently, modulating glycine and $\mathrm{GABA}_{\mathrm{A}}$ receptor-mediated presynaptic inputs to rod bipolar cells may influence the speed of A17 amacrine cell communication. Thus, the distinct inhibitory receptors on rod bipolar cell terminals shape the flow of information to A17 amacrine cells in separate ways. GABA and glycine signals originate in separate types of amacrine cells, which potentially have different spatial extents (Pourcho and Goebel, 1983; Vaney, 1990; Menger et al., 1998; O'Brien et al., 2003), but is not known whether $\mathrm{GABA}_{\mathrm{A}}$ and $\mathrm{GABA}_{\mathrm{C}}$ receptor-mediated signals originate from the same or separate amacrine cells. These separate signaling pathways could be independently modulated, suggesting an additional diversity for controlling glutamate release from rod bipolar cells.

\section{References}

Amin J, Weiss DS (1994) Homomeric rho 1 GABA channels: activation properties and domains. Receptors Channels 2:227-236.

Barbour B (2001) An evaluation of synapse independence. J Neurosci 21:7969-7984.

Berntson A, Smith RG, Taylor WR (2004) Postsynaptic calcium feedback between rods and rod bipolar cells in the mouse retina. Vis Neurosci 21:913-924.

Bloomfield SA, Xin D (2000) Surround inhibition of mammalian AII amacrine cells is generated in the proximal retina. J Physiol (Lond) 523 3:771-783.

Brickley SG, Cull-Candy SG, Farrant M (1996) Development of a tonic form of synaptic inhibition in rat cerebellar granule cells resulting from persistent activation of GABAA receptors. J Physiol (Lond) 497:753-759.
Brickley SG, Revilla V, Cull-Candy SG, Wisden W, Farrant M (2001) Adaptive regulation of neuronal excitability by a voltage-independent potassium conductance. Nature 409:88-92.

Cadetti L, Tranchina D, Thoreson WB (2005) A comparison of release kinetics and glutamate receptor properties in shaping rod-cone differences in EPSC kinetics in the salamander retina. J Physiol (Lond) 569:773-788.

Chang Y, Weiss DS (1999) Channel opening locks agonist onto the GABA receptor. Nat Neurosci 2:219-225.

Chen S, Diamond JS (2002) Synaptically released glutamate activates extrasynaptic NMDA receptors on cells in the ganglion cell layer of the rat retina. J Neurosci 22:2165-2173.

Chiu CS, Brickley S, Jensen K, Southwell A, McKinney S, Cull-Candy S, Mody I, Lester HA (2005) GABA transporter deficiency causes tremor, ataxia, nervousness, and increased GABA-induced tonic conductance in cerebellum. J Neurosci 25:3234-3245.

Christie JM, Jahr CE (2006) Multivesicular release at Schaffer collateralCA1 hippocampal synapses. J Neurosci 26:210-216.

Cohen I, van der Kloot W, Attwell D (1981) The timing of channel opening during miniature end-plate currents. Brain Res 223:185-189.

Cui J, Ma YP, Lipton SA, Pan ZH (2003) Glycine receptors and glycinergic synaptic input at the axon terminals of mammalian retinal rod bipolar cells. J Physiol (Lond) 553:895-909.

Diamond JS (2001) Neuronal glutamate transporters limit activation of NMDA receptors by neurotransmitter spillover on CA1 pyramidal cells. J Neurosci 21:8328-8338.

Diamond JS, Jahr CE (1995) Asynchronous release of synaptic vesicles determines the time course of the AMPA receptor-mediated EPSC. Neuron 15:1097-1107.

Dong C, Werblin FS (1998) Temporal contrast enhancement via GABA feedback at bipolar terminals in the tiger salamander retina. J Neurophysiol 79:2171-2180.

Dunning DD, Hoover CL, Soltesz I, Smith MA, O'Dowd DK (1999) GABA receptor-mediated miniature postsynaptic currents and alpha-subunit expression in developing cortical neurons. J Neurophysiol 82:3286-3297.

Eggers ED, Lukasiewicz PD (2006) $\mathrm{GABA}_{\mathrm{A}}, \mathrm{GABA}_{\mathrm{C}}$ and glycine receptormediated inhibition differentially affects light-evoked signalling from mouse retinal rod bipolar cells. J Physiol (Lond) 572:215-225.

Euler T, Wässle H (1998) Different contributions of $\mathrm{GABA}_{\mathrm{A}}$ and $\mathrm{GABA}_{\mathrm{C}}$ receptors to rod and cone bipolar cells in a rat retinal slice preparation. J Neurophysiol 79:1384-1395.

Feigenspan A, Bormann J (1994) Differential pharmacology of GABA-A and GABA-C receptors on rat retinal bipolar cells. Eur J Pharmacol 288:97-104.

Fletcher EL, Koulen P, Wässle H (1998) $\mathrm{GABA}_{\mathrm{A}}$ and $\mathrm{GABA}_{\mathrm{C}}$ receptors on mammalian rod bipolar cells. J Comp Neurol 396:351-365.

Frech MJ, Backus KH (2004) Characterization of inhibitory postsynaptic currents in rod bipolar cells of the mouse retina. Vis Neurosci 21:645-652.

Grudzinska J, Schemm R, Haeger S, Nicke A, Schmalzing G, Betz H, Laube B (2005) The beta subunit determines the ligand binding properties of synaptic glycine receptors. Neuron 45:727-739.

Hajos N, Mody I (1997) Synaptic communication among hippocampal interneurons: properties of spontaneous IPSCs in morphologically identified cells. J Neurosci 17:8427-8442.

Hamann M, Rossi DJ, Attwell D (2002) Tonic and spillover inhibition of granule cells control information flow through cerebellar cortex. Neuron 33:625-633.

Hefft S, Jonas P (2005) Asynchronous GABA release generates long-lasting inhibition at a hippocampal interneuron-principal neuron synapse. Nat Neurosci 8:1319-1328.

Ichinose T, Lukasiewicz PD (2002) GABA transporters regulate inhibition in the retina by limiting $\mathrm{GABA}_{\mathrm{C}}$ receptor activation. J Neurosci 22:3285-3292.

Jonas P, Bischofberger J, Sandkuhler J (1998) Corelease of two fast neurotransmitters at a central synapse. Science 281:419-424.

Keros S, Hablitz JJ (2005) Subtype-specific GABA transporter antagonists synergistically modulate phasic and tonic GABAA conductances in rat neocortex. J Neurophysiol 94:2073-2085.

Koulen P, Sassoe-Pognetto M, Grunert U, Wässle H (1996) Selective clustering of $\mathrm{GABA}_{\mathrm{A}}$ and glycine receptors in the mammalian retina. J Neurosci 16:2127-2140.

Koulen P, Brandstätter JH, Enz R, Bormann J, Wässle H (1998) Synaptic 
clustering of $\mathrm{GABA}_{\mathrm{C}}$ receptor r-subunits in rat retina. Eur J Neurosci 10:115-127.

Legendre P (1998) A reluctant gating mode of glycine receptor channels determines the time course of inhibitory miniature synaptic events in zebrafish hindbrain neurons. J Neurosci 18:2856-2870.

Lozovaya NA, Grebenyuk SE, Tsintsadze T, Feng B, Monaghan DT, Krishtal OA (2004) Extrasynaptic NR2B and NR2D subunits of NMDA receptors shape "superslow" afterburst EPSC in rat hippocampus. J Physiol (Lond) 558:451-463.

Lukasiewicz P, Shields C (1998) Different combinations of $\mathrm{GABA}_{\mathrm{A}}$ and $\mathrm{GABA}_{\mathrm{C}}$ receptors confer distinct temporal properties to retinal synaptic responses. J of Neurophysiol 79:3157-3167.

Lukasiewicz PD, Roeder RC (1995) Evidence for glycine modulation of excitatory synaptic inputs to retinal ganglion cells. J Neurosci 15:4592-4601.

Lukasiewicz PD, Maple BR, Werblin FS (1994) A novel GABA receptor on bipolar cell terminals in the tiger salamander retina. J Neurosci 14:1202-1212.

McCall MA, Lukasiewicz PD, Gregg RG, Peachey NS (2002) Elimination of the $\mathrm{r} 1$ subunit abolishes $\mathrm{GABA}_{\mathrm{C}}$ receptor expression and alters visual processing in the mouse retina. J Neurosci 22:4163-4174.

Menger N, Pow DV, Wässle H (1998) Glycinergic amacrine cells of the rat retina. J Comp Neurol 401:34-46.

O'Brien BJ, Richardson RC, Berson DM (2003) Inhibitory network properties shaping the light evoked responses of cat alpha retinal ganglion cells. Vis Neurosci 20:351-361.

O'Brien JA, Berger AJ (1999) Cotransmission of GABA and glycine to brain stem motoneurons. J Neurophysiol 82:1638-1641.

Okada M, Onodera K, Van Renterghem C, Sieghart W, Takahashi T (2000) Functional correlation of $\mathrm{GABA}_{\mathrm{A}}$ receptor $\alpha$ subunits expression with the properties of IPSCs in the developing thalamus. J Neurosci 20:2202-2208.

Pang JJ, Gao F, Wu SM (2004) Light-evoked current responses in rod bipolar cells, cone depolarizing bipolar cells and AII amacrine cells in darkadapted mouse retina. J Physiol (Lond) 558:897-912.

Pankratov YV, Krishtal OA (2003) Distinct quantal features of AMPA and NMDA synaptic currents in hippocampal neurons: implication of glutamate spillover and receptor saturation. Biophys J 85:3375-3387.

Pourcho RG, Goebel DJ (1983) Neuronal subpopulations in cat retina which accumulate the GABA agonist, $\left[{ }^{3} \mathrm{H}\right]$ muscimol: a combined Golgi and autoradiographic study. J Comp Neurol 219:25-35.

Prenosil GA, Schneider Gasser EM, Rudolph U, Keist R, Fritschy JM, Vogt KE (2006) Specific subtypes of GABAA receptors mediate phasic and tonic forms of inhibition in hippocampal pyramidal neurons. J Neurophysiol 96:846-857.
Qian H, Dowling JE (1993) Novel GABA responses from rod-driven retinal horizontal cells. Nature 361:162-164.

Qian H, Dowling JE (1995) GABAa and GABAc receptors on hybrid bass retinal bipolar cells. J Neurophysiol 74:1920-1928.

Rossi DJ, Hamann M (1998) Spillover-mediated transmission at inhbibitory synapses promoted by high affinity a6 subunit $\mathrm{GABA}_{\mathrm{A}}$ receptors and glomerular geometry. Neuron 20:783-795.

Rusakov DA, Kullmann DM (1998) Extrasynaptic glutamate diffusion in the hippocampus: ultrastructural constraints, uptake, and receptor activation. J Neurosci 18:3158-3170.

Sargent PB, Saviane C, Nielsen TA, DiGregorio DA, Silver RA (2005) Rapid vesicular release, quantal variability, and spillover contribute to the precision and reliability of transmission at a glomerular synapse. J Neurosci 25:8173-8187.

Schnapf JL, Copenhagen DR (1982) Differences in the kinetics of rod and cone synaptic transmission. Nature 296:862-864.

Shields CR, Tran MN, Wong RO, Lukasiewicz PD (2000) Distinct ionotropic GABA receptors mediate presynaptic and postsynaptic inhibition in retinal bipolar cells. J Neurosci 20:2673-2682.

Singer JH, Berger AJ (1999) Contribution of single-channel properties to the time course and amplitude variance of quantal glycine currents recorded in rat motoneurons. J Neurophysiol 81:1608-1616.

Sola E, Prestori F, Rossi P, Taglietti V, D’Angelo E (2004) Increased neurotransmitter release during long-term potentiation at mossy fibre-granule cell synapses in rat cerebellum. J Physiol (Lond) 557:843-861.

Takahashi T (2005) Postsynaptic receptor mechanisms underlying developmental speeding of synaptic transmission. Neurosci Res 53:229-240.

Takahashi T, Momiyama A, Hirai K, Hishinuma F, Akagi H (1992) Functional correlation of fetal and adult forms of glycine receptors with developmental changes in inhibitory synaptic receptor channels. Neuron 9:1155-1161.

Van der Kloot W (1988) Estimating the timing of quantal releases during end-plate currents at the frog neuromuscular junction. J Physiol (Lond) 402:595-603.

Vaney DI (1990) The mosaic of amacrine cells in the mammalian retina. Prog Retin Eye Res 9:49-100.

Vigh J, Li GL, Hull C, von Gersdorff H (2005) Long-term plasticity mediated by mGluR1 at a retinal reciprocal synapse. Neuron 46:469-482.

Wei W, Zhang N, Peng Z, Houser CR, Mody I (2003) Perisynaptic localization of $\delta$ subunit-containing $\mathrm{GABA}_{\mathrm{A}}$ receptors and their activation by GABA spillover in the mouse dentate gyrus. J Neurosci 23:10650-10661.

Werblin FS (1978) Transmission along and between rods in the tiger salamander retina. J Physiol (Lond) 280:449-470. 